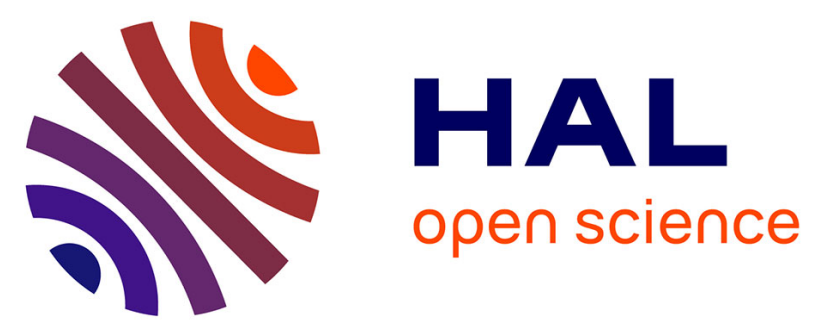

\title{
Transfer of dissolved gases through a thick karstic vadose zone - implications for recharge characterisation and groundwater age dating in karstic aquifers
}

Laïna Pérotin, Véronique de Montety, Bernard Ladouche, Vincent Bailly-Comte, Thierry Labasque, Virginie Vergnaud, Rémie Muller, Cedric Champollion, Sarah Tweed, J.L. Seidel

\section{To cite this version:}

Laïna Pérotin, Véronique de Montety, Bernard Ladouche, Vincent Bailly-Comte, Thierry Labasque, et al.. Transfer of dissolved gases through a thick karstic vadose zone - implications for recharge characterisation and groundwater age dating in karstic aquifers. Journal of Hydrology, 2021, 601, pp.126576. 10.1016/j.jhydrol.2021.126576 . insu-03266721

\section{HAL Id: insu-03266721 \\ https://hal-insu.archives-ouvertes.fr/insu-03266721}

Submitted on 22 Jun 2021

HAL is a multi-disciplinary open access archive for the deposit and dissemination of scientific research documents, whether they are published or not. The documents may come from teaching and research institutions in France or abroad, or from public or private research centers.
L'archive ouverte pluridisciplinaire HAL, est destinée au dépôt et à la diffusion de documents scientifiques de niveau recherche, publiés ou non, émanant des établissements d'enseignement et de recherche français ou étrangers, des laboratoires publics ou privés. 


\section{Journal Pre-proofs}

Research papers

Transfer of dissolved gases through a thick karstic vadose zone - implications for recharge characterisation and groundwater age dating in karstic aquifers

Laïna Pérotin, Véronique de Montety, Bernard Ladouche, Vincent BaillyComte, Thierry Labasque, Virginie Vergnaud, Rémie Muller, Cédric Champollion, Sarah Tweed, Jean-Luc Seidel

PII: S0022-1694(21)00623-5

DOI: $\quad$ https://doi.org/10.1016/j.jhydrol.2021.126576

Reference: $\quad$ HYDROL 126576

To appear in: $\quad$ Journal of Hydrology

Received Date: $\quad 13$ January 2021

Revised Date: 9 June 2021

Accepted Date: $\quad 14$ June 2021

Please cite this article as: Pérotin, L., de Montety, V., Ladouche, B., Bailly-Comte, V., Labasque, T., Vergnaud, V., Muller, R., Champollion, C., Tweed, S., Seidel, J-L., Transfer of dissolved gases through a thick karstic vadose zone - implications for recharge characterisation and groundwater age dating in karstic aquifers, Journal of Hydrology (2021), doi: https://doi.org/10.1016/j.jhydrol.2021.126576

This is a PDF file of an article that has undergone enhancements after acceptance, such as the addition of a cover page and metadata, and formatting for readability, but it is not yet the definitive version of record. This version will undergo additional copyediting, typesetting and review before it is published in its final form, but we are providing this version to give early visibility of the article. Please note that, during the production process, errors may be discovered which could affect the content, and all legal disclaimers that apply to the journal pertain.

(C) 2021 Published by Elsevier B.V. 
1 Transfer of dissolved gases through a thick karstic vadose zone -

2 implications for recharge characterisation and groundwater age dating in

3 karstic aquifers

4

5 Laïna Pérotin ${ }^{1}$, Véronique de Montety ${ }^{1}$, Bernard Ladouche ${ }^{2}$, Vincent Bailly-Comte ${ }^{2}$, Thierry

6 Labasque $^{3}$, Virginie Vergnaud ${ }^{3}$, Rémie Muller ${ }^{1}$, Cédric Champollion ${ }^{4}$, Sarah Tweed ${ }^{5}$, Jean-

7 Luc Seidel ${ }^{1}$

8 1: HSM, Université de Montpellier, CNRS, IRD, 300 avenue Emile Jeanbrau 34090 Montpellier, France

9 2: BRGM, Water Environment \& Ecotechnologies Division, 1039 rue de Pinville, F-34000 France Montpellier,

10 France

11 3: Plateforme Condate Eau, OSUR-Geosciences Rennes, Université Rennes1-CNRS, 35042 Rennes, France

12 4: Géosciences Montpellier, CNRS, Université Montpellier, UA, F-34095 Montpellier, France

13 5: UMR G-eau, IRD, Montpellier, France

14 Corresponding author: Laïna Pérotin (laina.perotin@umontpellier.fr)

Abstract:

This study analyses the impact of a thick vadose zone on gaseous transfers and Excess Air (EA) formation using dissolved noble and anthropogenic gas tracers ( $\mathrm{Ne}, \mathrm{Ar}, \mathrm{N}_{2}, \mathrm{CFC}$, $\mathrm{SF}_{6}, \mathrm{O}_{2}$ and $\mathrm{CO}_{2}$ ). Understanding gas transfers integrates the issues of equilibrium and water/air exchanges along the vadose zone. In this study, the noble and anthropogenic gases were analysed in air and water over vadose zone depths of $120 \mathrm{~m}$ and over two contrasted hydrodynamic periods therefore enabling a rare insight into the spatial and seasonal variations of equilibrium and water/air exchanges in a heterogeneous karst environment. The results highlight that both noble and anthropogenic gases of the caves are in equilibrium with the atmosphere up to at least depths of $120 \mathrm{~m}$. In water, the Noble Gas Temperature (NGT) remains stable at $8^{\circ} \mathrm{C}$ whilst some EA is formed (up to $1.3 \mathrm{~cm}^{3} \mathrm{STP} / \mathrm{kg}$ at $\left.120 \mathrm{~m}\right)$ during transfers in the vadose zone. The high EA value measured at the spring outlet cannot be explained by an increase during transfers via the vadose zone. This high EA value is due to rapid and high water level variations during recharge. The implications of these results are important to advance our understanding in the use of noble and anthropogenic gases in characterising recharge 
and quantifying groundwater ages. In particular, these results help to identify the parts of the aquifer actively involved in dissolved gas transfers, highlight the futility of using a time-lag factor for groundwater age dating in karstic systems, and improve our understanding of the EA formation processes.

Keywords: dissolved gases, Excess Air (EA), karstic aquifers, thick vadose zone, transfers, recharge, dating gaseous tracers

\section{Introduction}

In karts systems, the vadose zone, composed of soil, epikarst and the unsaturated zone (Stephens, 1996), plays an important role in controlling the recharge processes of groundwater. Several methods exist to investigate transfers of water along the vadose zone and address the question of storage dynamics or travel time estimation of recharge water. For example, many studies of cave drips have been carried out and provide information on the capacitive role of the epikarst (Williams, 1983; Tooth and Fairchild, 2003; Musgrove and Banner, 2004; Fairchild et al., 2006; Garry et al., 2008; Arbel et al., 2010; Kluge et al., 2010; Poulain et al., 2015). Another approach is numerical modelling, which has the advantage of being applicable on a large scale and over longtime frames. Models based on physical processes and using Richard's equations are applied to the porous vadose zone, that can be assimilated to homogeneous aquifers (Vereecken et al., 2008). These physically-based approaches are interesting since they can deal with the degree of saturation of the vadose zone. However, they cannot take into account the heterogeneous properties of karst (Šimůnek et al., 2003), which is why their application is scarce in karst aquifers.

Globally, karstic aquifers provide important groundwater resources (e.g. Bakalowicz, 2005; Stevanović, 2018, 2019; Goldscheider et al., 2020;). However, these aquifers are renowned for their heterogeneous structures, including large voids (conduits), associated with a porous matrix that induce spatially heterogeneous hydrodynamic and hydrochemical properties (Bakalowicz, 2008). This heterogeneity 
challenges the use of classical hydrogeological methods of investigation, including the basic piezometric map. To face these issues, development of additional innovative methods is essential to investigate and provide an understanding of karst aquifer functioning, especially within the vadose zone.

Hydrogeochemical methods integrate heterogeneities at the scale of the catchment with a large number of tracers that are commonly combined (Barnes and Allison, 1988; Plagnes, 1997; Pinault et al., 2001; Perrin et al., 2003; Tooth and Fairchild, 2003; Musgrove and Banner, 2004; Aquilina et al., 2005; Carrasco et al., 2006; Fairchild et al., 2006; Kluge et al., 2010; Knierim et al., 2013; Kogovsek and Petric, 2014). Such methods are appropriate for investigating groundwater-rock interactions, origin and mixing of waters, and degrees of karstification (Sánchez et al., 2015). However, they fail to inform about physical processes such as air/water equilibrium, matrix/conduits exchange and recharge conditions that affect water transfers from the surface to the spring. In particular, little is known of the temperature and pressure conditions during recharge, even though such parameters can be critical in understanding hydrogeological processes.

Dissolved gases are sensitive to recharge conditions as their solubility in water depends on recharge temperature, salinity and pressure (Weiss, 1970, 1971). For noble gases, since their partial pressure in the atmosphere remains stable, their concentration in water only depends on the recharge conditions and especially temperature (Aeschbach-Hertig et al., 1999, 2000; Manning and Solomon, 2003; Ingram et al., 2007). With inverse models, noble gases have been used to determine the groundwater recharge temperature, known as Noble Gas Temperature NGT, (Aeschbach-Hertig et al., 1999; Ballentine and Hall, 1999), which in turn can be used to infer information about the recharge period (Chatton et al., 2016).

Moreover, numerous studies have shown that the concentrations of dissolved noble gases in water can be higher than expected from the application of Henry's law (Herzberg and Mazor, 1979; Heaton and Vogel, 1981; Stute et al., 1995). This phenomenon is known as Excess Air (EA). It is usually taken into account as a corrective term of dissolved gas concentrations in the application of dating methods using gases tracers such as CFCs, $\mathrm{SF}_{6}$ or He. Two assumptions have been made for EA formation. 
94 Firstly, Herzberg and Mazor (1979) and Mazor et al. (1983) suggested that during water transfers along the vadose zone the air is sucked into the water. In this case, the quantity of EA formed is linked to the vadose zone thickness. Secondly, Stute and Schlosser (2000) and Aeschbach-Hertig (2004) explained that EA formation is via the entrapment of air bubbles after a rapid increase in the water table, where the hydrostatic pressure increases during the water level change forces gas dissolution. In this case, concentrations of EA depend on water table fluctuations with higher values due to rapid and larger increases in the water table (Ingram et al., 2007; Massmann and Sültenfub, 2008).

In karst systems the vadose zones are often thick, for example, in the Mediterranean area the vadose zone can be up to 400m (Mudry and Puig, 1991; Fleury et al., 2007). Moreover, groundwater levels in karst aquifers can undergo rapid increases during recharge events (several tens of meters; e.g. Bailly-Comte et al., 2008). Finally, in karst systems the presence of an epikarst can often be associated with perched water tables (Klimchouk et al., 2000; Bakalowicz, 2004; Klimchouk, 2004). Such characteristics can significantly impact air/water equilibrium, gas transfers and EA formation. Despite this, the composition and evolution of the dissolved gases in the vadose zones of karstic systems are poorly documented.

Therefore, the use of dissolved gases in karst systems raises the following fundamental questions relating to the processes of air-water equilibrium (i) does the equilibrium occur at the surface of the epikarst or at the surface of the water table (base of the vadose zone); (ii) if the equilibrium is located at the surface of the epikarst, is the air in caves located at the bottom of a thick unsaturated zone still equilibrated with the atmospheric air; and (iii) is there re-equilibration during transfers along the thick vadose zone? Such questions are important for the application of noble gases as environmental tracers of recharge mechanisms in karst aquifers. In particular, the study

120 of $E A$ is required to improve our understanding of links with the aquifer structure 121 and/or hydrodynamics, and the quantification of groundwater ages using gaseous dating 122 tracers (e.g. CFCs and $\mathrm{SF}_{6}$ ).

To address these questions, in this study the dissolved noble and anthropogenic 124 gas tracers (neon ( $\mathrm{Ne})$, argon ( $\mathrm{Ar}$ ), nitrogen $\left(\mathrm{N}_{2}\right)$, chlorofluorocarbons (CFCs) and sulfur 
125 hexafluoride $\left(\mathrm{SF}_{6}\right)$ ) were measured in both air and water at different depths along a

126 thick vadose zone (120 m deep) of a karst aquifer with a well-developed epikarst. This

127 allowed us to identify the (i) air composition evolution along the vadose zone and its

128 equilibrium with the atmosphere; (ii) gas evolution in air and in water to identify the 129 equilibrium depth for dissolution of gases; and (iii) mechanisms of EA formation in a 130 karstic system.

1312 Study area

132 The area of investigation is located in a Jurassic carbonate plateau of the Causse 133 du Larzac (south of France), and has an elevation between 700 and $900 \mathrm{~m}$ asl. This 134 site is part of the Natural Regional Park of the Grand Causse (PNRGC). It is one of the 135 study sites of the French National Observation Services $\mathrm{H}+$ (http://hplus.ore.fr/), which 136 is part of the Elter European Infrastructure (https://deims.org/83b01fa5-747f-47be-9185137 408d73a90fb2), and has therefore been extensively studied ( Plagnes, 1997; Bruxelles, 138 2001; Jacob, 2009; Tritz et al., 2011; Deville, 2013; Fores, 2016). Two main aquifer 139 reservoirs are present: i) dolomites and limestone of the Early Jurassic and ii) the 140 Middle to Upper Jurassic. These two carbonated series are separated by the Toarcian 141 marls that outcrop at the Hospitalet's fault, which constrains the emergence of the 142 Durzon's spring at the base of the carbonate series (fig 1-A).

143 The climate of the Causse du Larzac is Mediterranean, defined by wet winter 144 and spring months, and a dry summer. Autumn is characterised by intense rainfall 145 events caused by Cevenol episodes, with rainfall peaks that can reach up to 290 $146 \mathrm{~mm} /$ day. This period constitutes an important recharge period for the aquifer. In this 147 study, we refer to high and low flow periods to define two states observed during the 148 hydrological cycle. The high flow period results from the autumn, winter and spring 149 rainfall recharge, and is characterised by high spring flow and groundwater levels 150 towards the beginning of the dry season. The low flow period is mainly during the dry 151 season when the spring flow and groundwater levels are lower.

152 The mean potential evapotranspiration is $2.5 \mathrm{~mm} /$ day with a maximum value of $1539 \mathrm{~mm} /$ day during summer. The air temperature is between $-14^{\circ} \mathrm{C}$ and $35^{\circ} \mathrm{C}$ with an 
154 average of $11^{\circ} \mathrm{C}$. During recharge periods of spring and autumn the average monthly

155 air temperatures vary between $6^{\circ} \mathrm{C}$ and $16^{\circ} \mathrm{C}$.

The Durzon's spring, located at $533 \mathrm{~m}$ asl with a mean flow of $1.5 \mathrm{~m}^{3} / \mathrm{s}$ (Tritz et al., 2011), drains a surface area between 98 and $117 \mathrm{~km}^{2}$ (estimated by dye tracing; Ricard and Bakalowicz, 1996; Fores, 2016) (Fig. 1-A). The aquifer is unconfined in the two blocks located on each side of the Hospitalet fault. The saturated zone is developed within the Middle Jurassic Dolomite in the southern region and both within the Middle Jurassic dolomite and the Middle Jurassic limestone to the north of the Hospitalet fault. The Durzon spring is the main spring that drains the catchment, and therefore represents catchment-scale hydrodynamic and hydrogeochemical information. The Durzon system is characterised by a thick vadose zone (up to $120 \mathrm{~m}$ deep, south of the Hospitalet's fault), and an epikarst developed in the dolomite (weathered to dolomitic sands) especially in the southern part of the catchment. This lithology allows an important storage of water in the near-surface. One manifestation of this storage is the formation of temporary lakes, mainly located south of the catchment, that were last filled in 2014 (Fores, 2016). These changes in geology, vadose zone depths and epikarst thicknesses results in heterogeneous hydraulic properties of the vadose zone between the southern and the northern regions of the Durzon spring catchment.

Water storage in the vadose zone of the study area has previously been investigated through the use of several geophysical methods that couple gravimetry and seismology with hydrology. These studies confirmed the important role of the epikarst for vadose zone water storage (Jacob, 2009; Deville, 2013). In addition, the fluxes from the epikarst were modeled based on continuous gravimetric measurements (site of La Jasse, the Larzac Observatory). The results showed that this flow corresponds to the spring's base flow (Fores et al., 2017).

Several accessible caves in the vadose zone are present in the southern area of the Hospitalet's fault. The Bise cave reaches a depth of $120 \mathrm{~m}$ from the grounds surface, and there is a stream that flows through the cave that is disconnected from the saturated zone. 

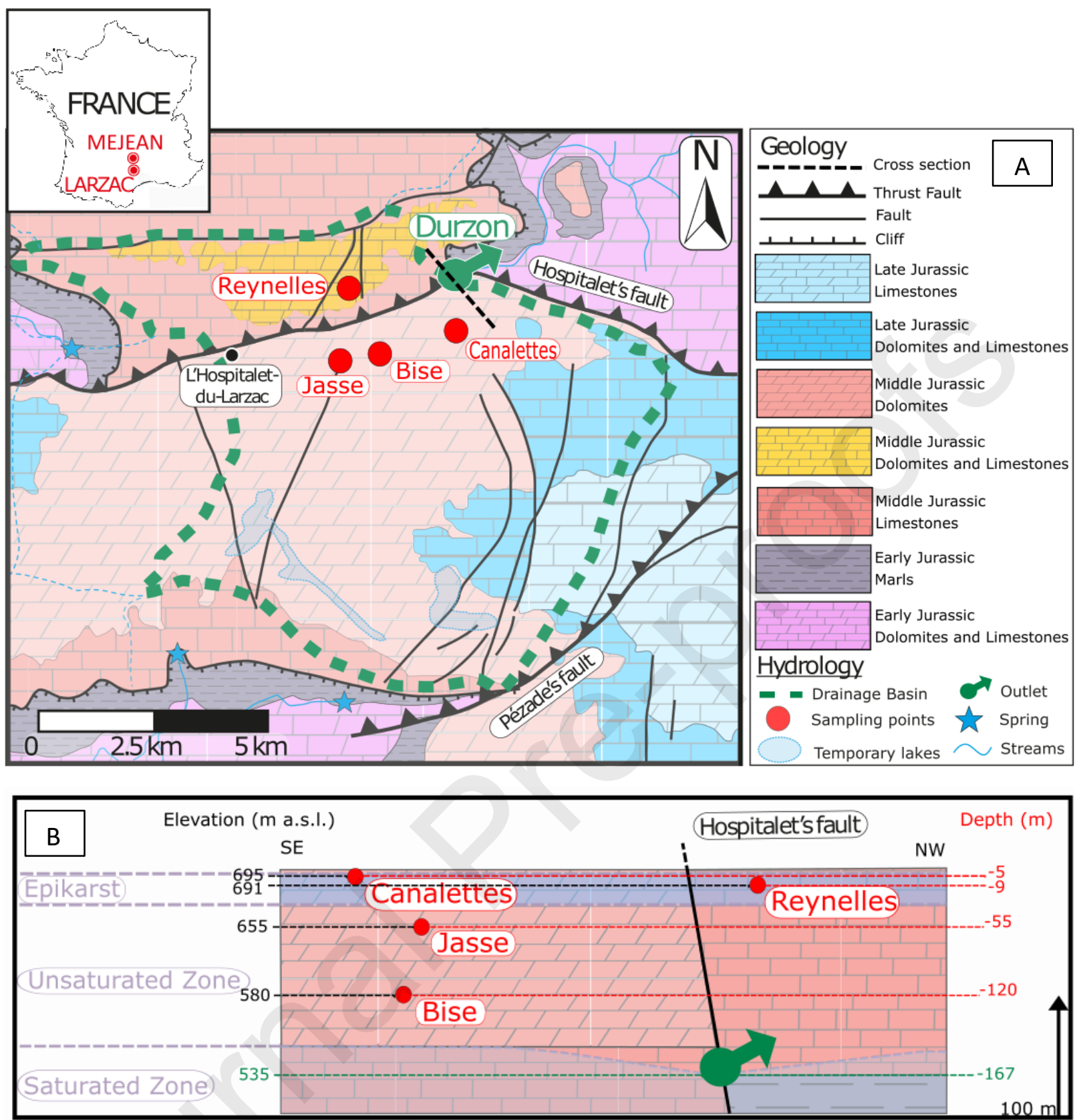

Fig 1. (A) Geological map of the Durzon karst system (modified from Fores, 2016). (B) Schematic cross-section at the Durzon spring highlighting with the location of sampling points with depth in the vadose zone, and hypothetic

Based on the analysis of the Durzon spring recession curves, the karst system 189 shows a high dynamic volume (Mangin, 1975), which highlights the presence of large 190 groundwater reserves at the site (Plagnes, 1997). Chemical variations are low during 191 seasonal hydrological changes, except for a significant increase in the specific conductivity $(\mathrm{SpC})$ and a decrease in the $\mathrm{Mg}^{2+}$ concentrations that result from the fast 193 infiltration after recharge events (Plagnes, 1997). High values of $\mathrm{Mg}^{2+}$ concentrations 
194 are correlated to the extension of the ruiniform dolomites from the Bathonian at the 195 surface of the catchment (Plagnes, 1997).

196 Another catchment has been used, the Ironselle catchment located on the nearby

197 Causse Méjean, $25 \mathrm{~km}$ north of the Durzon spring, and developed in the same geological

198 and climatic context as the Durzon spring catchment. It presents a comparable structure

199 of a carbonate plateau developed in dolomites and limestone from the Jurassic, but 200 has a thicker vadose zone than the Durzon's catchment allowing a deeper sampling at $201395 \mathrm{~m}$ depth (the only site sampled on this catchment).

2023 Methods

203

\subsection{Dataset}

204 Spring discharge (hourly time step since 1998), water temperature and specific 205 conductivity (30 min time step since Dec-2011) are monitored by the Regional Natural Park of the Grands Causses (PNRGC). Dissolved gas samples for CFC-12, SF $6, \mathrm{Ne}, \mathrm{Ar}$ and

$207 \mathrm{~N}_{2}$ analysis have been collected at the Durzon spring from 2009 to 2019 with a monthly 208 time step between February 2010 and November 2011 (de Montety et al., 2012). These 209 measurements of gases in the spring were compared with the data obtained in the 210 vadose zone, at different stages of the hydrological cycle, to determine whether the 211 vadose zone data can partly or fully explain the spring data.

212 The presence at different depths of the vadose zone of small streams or cavities 213 containing water allows the sample of gases in air and in water along the vadose zone 214 (Fig. 1-B). Four locations (shown in Fig. 1-A) with contrasted depths have been sampled 215 to describe both the epikarstic and vadose zone: Canalettes and Reynelles at 5 and 9 $216 \mathrm{~m}$ depth respectively for the epikarstic zone, a $45 \mathrm{~m}$ deep borehole in the unsaturated 217 zone (Jasse), and an underground river at $120 \mathrm{~m}$ depth in the unsaturated zone (Bise). 218 In addition, air was sampled at the land's surface (700 $\mathrm{m}$ a.s.l) and water was also 219 sampled at the Durzon spring. Two sampling campaigns were undertaken during high 220 and low flow conditions (March-2018 and Sept-2019 respectively) to evaluate the

221 seasonal hydrological influence on the gas transfers. 
Rainfall and potential evapotranspiration data used in this study are collected by

223 Météo-France on Le Caylar station, located $14 \mathrm{~km}$ south of the site, providing daily data

224 since 2004. Air temperature is monitored by a flux tower located on the catchment.

225 The air temperature in the cave of la Bise is buffered to $10.8^{\circ} \mathrm{C}$ all year round

226 (pers. comm.). The water level is also monitored in the vadose zone since 2013 in two

227 boreholes of 20 and $51 \mathrm{~m}$ depth located on the La Jasse site (Fig. 1-A) and equipped

228 with a SWS CTD Diver ${ }^{\circledR}$ since 2013.

229 To complement the Durzon spring data, samples were also collected during the 230 low flow period in a similar karstic catchment, the Ironselle catchment. Air samples 231 were collected at $395 \mathrm{~m}$ depths in the Cheminée cave at the Ironselle catchment.

232

\subsection{Sampling and analysis}

Air samples for noble gas analysis were collected by filling $130 \mathrm{~mL}$ glass bottles sealed with rubber caps using syringes. The air volume of the bottle was renewed 3 times before sampling with a slight overpressure to avoid later contamination from atmospheric air. Dissolved noble gases in water were collected in $500 \mathrm{~mL}$ glass bottles closed with rubber caps and sealed by a metal ring. A small submergable pump (Mini Twister 12 volts standard PVC - sdec-france) was used to sample the Ironselle spring and the cave waters. At the Canalettes ( $5 \mathrm{~m}$ depth), a peristaltic pump was required due to the very low flow rate. For the Jasse borehole (45 $\mathrm{m}$ depth) and the Durzon

242 spring, a Grundfos MP1 pump was used. Samples were collected under water (directly

243 in the groundwater or in a bucket) to avoid any air contamination, after having renewed

244 the water 3 times. Two or three replicates were collected for each sampling point. CFC 245 and $\mathrm{SF}_{6}$ water samples were collected without atmospheric contact in stainless-steel 246 ampoules of $40 \mathrm{ml}$ (CFC) and $300 \mathrm{ml}\left(\mathrm{SF}_{6}\right)$ closed with two stainless-steel three-way 247 valves. In addition, for each dissolved gas sample, physico-chemical parameters $\left(\mathrm{T}^{\circ} \mathrm{C}\right.$, $248 \mathrm{pH}, \mathrm{SpC}$ and dissolved oxygen (DO)) were recorded using a portable multimeter HQ40D $249 \mathrm{HACH}$. Only the groundwater temperature at the Jasse borehole was measured by the 250 CTD Diver ${ }^{\circledR}$ located in the borehole, rather than at the land's surface with the portable 251 multimeter HQ40D $\mathrm{HACH}$. 
Both air and water samples were analysed at the CONDATE Eau analytical

253 platform, University of Rennes, by gas chromatography analysis. For water sample 254 analyses, Ne-Ar- $\mathrm{N}_{2}$ were extracted by head space and measured by gas chromatography 255 using a catharometer detector ( $\mu$ GC 3000 - SRA), with a precision of $8 \%$ for $\mathrm{Ne}$ and $2565 \%$ for $\mathrm{Ar}$ and $\mathrm{N}_{2}$. CFCs and $\mathrm{SF}_{6}$ were extracted by the purge and trap method to 257 concentrate the gases and quantified by gas chromatography with an electron capture 258 detector (Labasque et al., 2014, 2006). The analyses are within a precision of $3 \%$ for 259 CFC-12 and 5\% for $\mathrm{SF}_{6}$ in water. For air samples, excluding the extraction of gases from 260 the liquid phase, the analytical process was the same as for water samples. The 261 precision (repeatability) is about 10\%, mainly due to the low pressure of air samples, 262 and then possible contaminations. Air has been sampled at the surface of the catchment 263 (March 2018 - high flow campaign) and in the analysis laboratory (September 2019 264 low flow campaign) for the calibration. Every air sample was corrected from this 265 calibration.

\subsection{Calculation of recharge conditions (NGT and EA)}

$\mathrm{Ne}, \mathrm{Ar}$ and $\mathrm{N}_{2}$ can be used to estimate Noble Gas Temperature (NGT) and Excess Air (EA) (e.g. Heaton and Vogel, 1981; Plummer et al., 2004, Chatton et al., 2016). $\mathrm{N}_{2}$ 270 is a major gas, which can be produced by biological reactions such as denitrification in 271 anoxic systems (Blicher-Mathiesen et al., 1998; Mariotti, 1986; Smith et al., 1991). 272 However, in karst systems anoxic conditions are rarely found, especially in an unconfined 273 reservoir. For the Durzon system, the dissolved oxygen (DO) is always above $7.6 \mathrm{mg} / \mathrm{l}$. 274 For this reason, the $\mathrm{N}_{2}$ dissolved concentration was assumed to remain stable during 275 the hydrological cycle and was used to deduce NGT and EA.

Calculations were performed using the Unfraction Air (UA) conceptual model, 277 following the methodology described by Aeschbach-Hertig and Solomon (2013). This 278 simple model does not include degassing or gas partitioning. According to this model, 279 the concentration of the dissolved gas $(i)$ is given by:

$$
C_{i}\left(T, S, P, E A_{U A}\right)=C_{i}^{*}(T, S, P)+E A_{U A} * z_{i}
$$


281 where EAUA is the concentration of dissolved dry air in water; $z_{i}$ the volume fraction of 282 the gas $i$ in dry air (corresponding to $x_{i}$, the molar fraction) and $C_{i}{ }^{*}$ is the moist air 283 solubility equilibrium concentration at the given recharge temperature $\left(T^{\circ} \mathrm{K}\right)$, salinity $(S$ $284 \%$ ) and pressure ( $P$ atm) (Heaton and Vogel, 1981).

285

An inverse approach (Aeschbach-Hertig et al., 1999; Manning and Solomon, 2003) was also applied, where the model calculates the gas concentrations (mol/L) by applying Henry's law for varying NGT and EA parameters. The best set of NGT and EA was obtained after minimization of the $\chi^{2}$ function using the following equations:

$$
X^{2}=\frac{\sum\left(C i_{\text {measured }}-C i_{\text {calculated }}\right)^{2}}{\sigma^{2}}
$$

Equation 2

291 with

$$
C i_{\text {calculated }}=\left(\frac{\beta_{i}}{22,4} \times x_{i}(g) \times\left(P-p_{H 2 O}\right)\right)+\left(\frac{x_{i}}{V_{M}} \times \frac{\boldsymbol{E} \boldsymbol{A}}{1000}\right)
$$

Equation 3

292 where $\beta_{i}$ is the Bunsen coefficient of dissolution (L/L atm), $x_{i}$ the molar fraction of the 293 gas in dry air, $\mathrm{P}$ the pressure (atm), $\mathrm{p}_{\mathrm{H} 2 \mathrm{O}}$ the humidity pressure (atm), $\mathrm{V}_{\mathrm{M}}$ the molar 294 volume of the gas $(\mathrm{L} / \mathrm{mol})$ and EA the Excess Air $\left(\mathrm{cm}^{3} \mathrm{STP} / \mathrm{kg}\right)$.

295

$$
\begin{aligned}
\ln \beta=a_{1}+ & a_{2}\left(\frac{100}{\boldsymbol{T}}\right)+a_{3} \ln \left(\frac{\boldsymbol{T}}{100}\right) \\
& +S\left[b_{1}+b_{2}\left(\frac{\boldsymbol{T}}{100}\right)+b_{3}\left(\frac{\boldsymbol{T}}{100}\right)^{2}\right]
\end{aligned}
$$
(recharge temperature in ${ }^{\circ} \mathrm{K}$ ) and $\mathrm{S}$ the salinity (\%o). The salinity of groundwater from the Durzon and Ironselle aquifers is low $(<0.5 \%$ o), therefore the salinity correction can be neglected and fixed at 0 (Aeschbach-Hertig et al., 2000, 1999; Andrews and Lee, 1979). 
303

$$
P=\exp \left(\frac{-H}{2300}\right)
$$

Equation 5

304 Where $\mathrm{H}$ is the recharge altitude $(\mathrm{m})$.

305

306

To take into account the analytical uncertainties, we used a Monte Carlo approach. 100 random concentrations are drawn for each gas based on a normal distribution centred on the measured value and within the range of the analytical error. Then, 100 sets of parameters are calculated. The uncertainty of NGT and EA was given by the standard deviation of these 100 simulations.

The gas result corresponds to the mean value of the replicate samples collected at each point. The final uncertainty corresponds to the largest magnitude of each uncertainty including the duplicate uncertainty.

We compared the results from our method of calculation using three gases to the results from the use of five noble gases using the work from Holocher et al. (2002).

317 This comparison shows that the accuracy of the NGT and the EA is more dependent on the analytical uncertainties than the number of gases used for the calculation. The use of $\mathrm{Ar}$ and $\mathrm{Ne}$ is sufficient to determine NGT and EA as their dissolution highly depends on the variation of temperature and pressure respectively.

\subsection{Calculation of $\mathrm{CFC}-12$ and $\mathrm{SF}_{6}$ atmospheric pressures}

Determination of groundwater ages and flow models relies on the calculation of atmospheric mixing ratio (pptv) using Henry's law (International Atomic Energy Agency, 2006). The influence of the recharge elevation is small for elevations less than $1000 \mathrm{~m}$

326 (International Atomic Energy Agency, 2006) and has been fixed to $700 \mathrm{~m}$ asl in this

327 study. In contrast, recharge temperature is an essential parameter to calculate the 328 coefficient of solubility $\left(\beta_{\mathrm{i}}\right)$. The annual air temperature can be assumed to be close to 329 the recharge temperature (Herzberg and Mazor, 1979). However, air temperature data representative of the recharge sites is not always available or known; therefore, another approach is to calculate the recharge temperature based on the water NGT. In this 
332

333

334

335

336

337

338

339

340

341

342

343

344

345

346

347

348

349

350

351

352

353

354

355

356

357

study, we used the NGT, as we generally sampled noble gases and anthropogenic gases at the same time. However, we noticed some analytical problems for the dissolved noble gases sampled in September 2019 (low flow period), limiting their use for estimating the NGT for this campaign. Therefore, the mean NGT $\left(9.1^{\circ} \mathrm{C} \pm 2.2^{\circ} \mathrm{C}\right)$ calculated during low flow periods at the Durzon spring between 2009 and 2013 (6 values) was used. The same procedure was applied for EA computation, which is an essential corrective term especially for $\mathrm{SF}_{6}$ values.

\section{Results}

\subsection{Evolution of gaseous tracers along the vadose zone - results} in air samples

The gas composition of air samples in caves according to depth is reported in table 1 and Fig 2. During the high flow period (March), the proportion of $\mathrm{O}_{2}, \mathrm{Ne}, \mathrm{Ar}$ and $\mathrm{N}_{2}$ remains stable with depth, with a concentration that is close to the atmospheric air reference (Fig. 2 and table 1). In contrast, the proportion of $\mathrm{CO}_{2}$ increases from the atmospheric value at the ground surface (430 ppm) to $2200 \mathrm{ppm}$ at $120 \mathrm{~m}$ depth (Bise; Fig. 2). During the low flow period (September) a greater $\mathrm{CO}_{2}$ increase with depth was observed, with $\mathrm{CO}_{2}$ values almost doubled compared to high flow (from 2200 to 4200 ppm; Table 1) at the Bise in the Durzon spring catchment. In the Ironselle spring catchment, the $\mathrm{CO}_{2}$ values at $395 \mathrm{~m}$ depth during the low flow period reached up to 7400 ppm (Table 1).

The fractions of $\mathrm{O}_{2}, \mathrm{Ne}, \mathrm{Ar}$ and $\mathrm{N}_{2}$ in air obtained at the different sampling points were similar to the atmospheric reference values. These results indicate that the air composition of the caves in the vadose zone is equilibrated with atmospheric air during both high and low flow periods. 
Table 1: Proportions of O2, CO2, N2, Ne and Ar in cave air along the vadose zone profile in the Durzon catchment during high flow (March 2018) and low flow (September 2019), and in the deep Cheminée Cave located in the

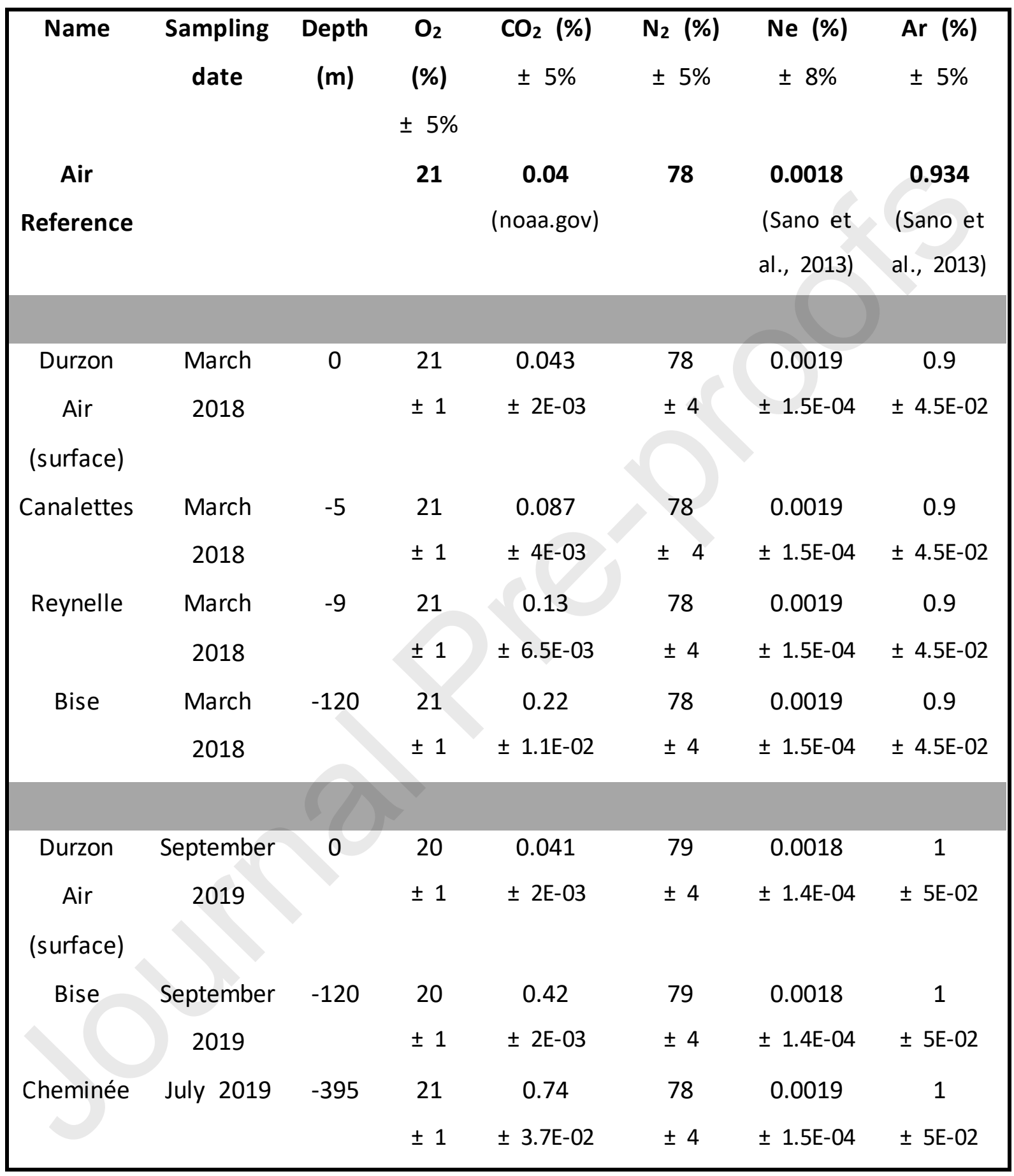




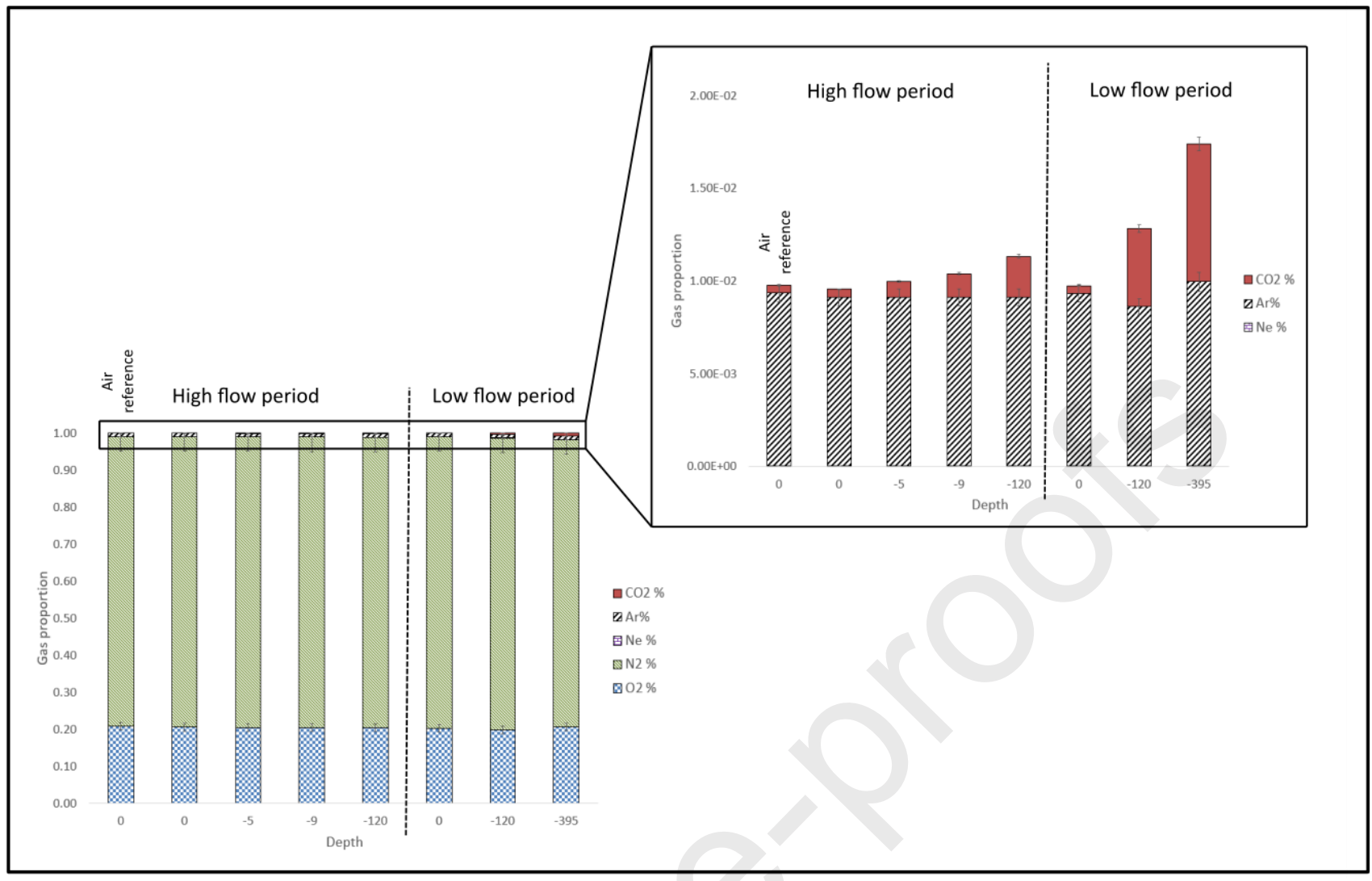

363 Fig 2 : Evolution of Ar-Ne- $\mathrm{N}_{2}-\mathrm{CO}_{2}-\mathrm{O}_{2}$ proportions in air caves of the Durzon and Ironselle spring catchments during the transfer along the unsaturated zone - High flow period: sampling in March 2018; Low flow period: sampling in

$\mathrm{O}_{2}, \mathrm{Ne}, \mathrm{Ar}$ and $\mathrm{N}_{2}$ cannot inform about the potential time lag during transfers

367 via the vadose zone, due to their constant atmospheric concentrations over time.

368 Therefore, to investigate potential time lags during transfers the anthropogenic gases

369 CFCs and $\mathrm{SF}_{6}$ were used. The atmospheric concentrations of these gases have evolved

370 since their industrial production in the 1950s and are well described (International

371 Atomic Energy Agency, 2006). 
Table 2: Fraction of CFCS and $\mathrm{SF}_{6}$ (pptv) in air caves along the vadose zone profile on the Durzon catchment during high flow (March 2018) and low flow (October 2019).

\begin{tabular}{|c|c|c|c|c|c|c|}
\hline Name & Sampling date & $\begin{array}{l}\text { Depth } \\
\text { (m) }\end{array}$ & $\begin{array}{c}\text { CFC-11 } \\
\text { corrected } \\
\text { (pptv) }\end{array}$ & $\begin{array}{c}\text { CFC-12 } \\
\text { corrected } \\
\text { (pptv) }\end{array}$ & $\begin{array}{l}\text { CFC-113 } \\
\text { corrected } \\
\text { (pptv) }\end{array}$ & $\begin{array}{c}\text { SF6 } \\
\text { corrected } \\
\text { (pptv) }\end{array}$ \\
\hline $\begin{array}{c}\text { USGS } \\
\text { (air reference NH) }\end{array}$ & 2018 & & $\begin{array}{l}219.30 \\
\pm 0.5\end{array}$ & $\begin{array}{c}515.74 \\
\pm 1\end{array}$ & $\begin{array}{r}70.34 \\
\pm 0.5\end{array}$ & $\begin{array}{r}9.37 \\
\pm 0.05\end{array}$ \\
\hline $\begin{array}{c}\text { Surface } \\
\text { (air in study area) }\end{array}$ & March 2018 & 0 & $\begin{array}{r}219 \\
\pm 21\end{array}$ & $\begin{array}{r}516 \\
\pm 50\end{array}$ & $\begin{array}{c}70 \\
\pm 15\end{array}$ & $\begin{array}{c}9.4 \\
\pm 1.7\end{array}$ \\
\hline Canalettes & March 2018 & -5 & $\begin{array}{l}213 \\
\pm 20\end{array}$ & $\begin{array}{r}508 \\
\pm 48\end{array}$ & $\begin{array}{r}57 \\
\pm \quad 6.3\end{array}$ & $\begin{array}{r}9.2 \\
\pm 0.9\end{array}$ \\
\hline Reynelle & March 2018 & -9 & $\begin{array}{r}237 \\
\pm 21\end{array}$ & $\begin{array}{r}549 \\
\pm 53\end{array}$ & $\begin{array}{c}74 \\
\pm 16\end{array}$ & $\begin{array}{c}9.9 \\
\pm 0.9\end{array}$ \\
\hline Bise & March 2018 & -120 & $\begin{array}{r}215 \\
\pm 32\end{array}$ & $\begin{array}{r}504 \\
\pm 65\end{array}$ & $\begin{array}{c}55 \\
\pm 13\end{array}$ & $\begin{array}{c}9.2 \\
\pm 1.0\end{array}$ \\
\hline $\begin{array}{c}\text { USGS } \\
\text { (air reference } \mathrm{NH} \text { ) }\end{array}$ & 2019 & & & & & \\
\hline $\begin{array}{l}\text { Air_labo } \\
\text { (air in the analytic } \\
\text { laboratory) }\end{array}$ & October 2019 & 0 & $\begin{array}{l}217 \\
\pm 48\end{array}$ & $\begin{array}{c}513 \\
\pm 116\end{array}$ & $\begin{array}{c}70 \\
\pm 17\end{array}$ & $\begin{array}{c}9.7 \\
\pm 1.4\end{array}$ \\
\hline Bise & $\begin{array}{c}\text { September } \\
2019\end{array}$ & -120 & $\begin{array}{l}161 \\
\pm 27\end{array}$ & $\begin{array}{l}524 \\
\pm 70\end{array}$ & $\begin{array}{c}71 \\
\pm 10\end{array}$ & $\begin{array}{c}10 \\
\pm 1.3\end{array}$ \\
\hline
\end{tabular}


The evolution of the gases (CFCs and $\mathrm{SF}_{6}$ ) with depth; from the surface to $120 \mathrm{~m}$ in the vadose zone, remains stable within the uncertainty (Fig. 3). These results

378 show that the CFCs and $\mathrm{SF}_{6}$ of air in caves is equilibrated with the atmosphere up to 379 depths of $120 \mathrm{~m}$. These observations suggest a good aeration of caves and shows that 380 the time lag had not affected the samples, even at $120 \mathrm{~m}$ depth.

382

383

384 385

386

387

\section{Dry air mole fraction (pptv)}

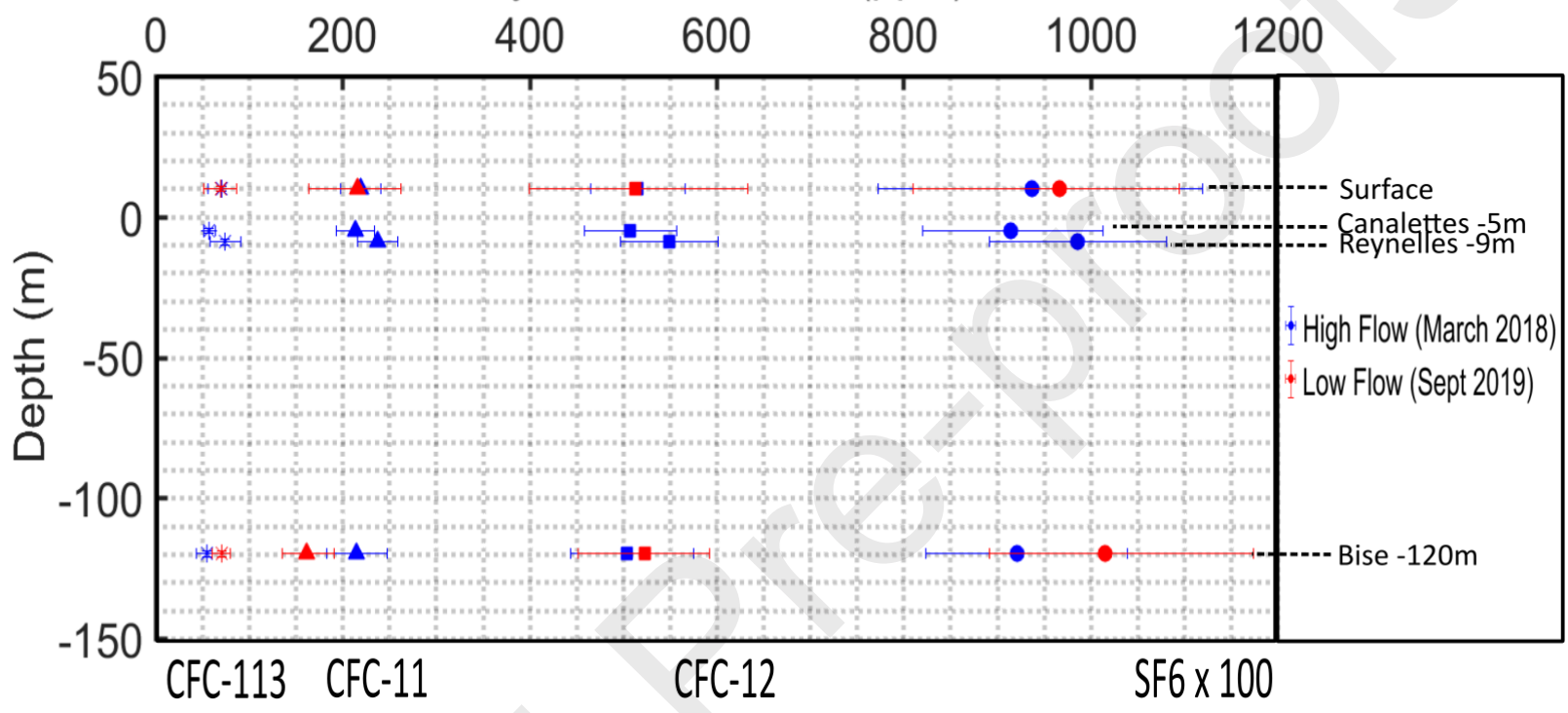

Fig 3: Evolution of CFCS and $\mathrm{SF}_{6}(x$ 100) in the air of the vadose zone of Durzon karstic system - corrected data from surface samples - Surface data in low flow period corresponds to the air in the analytical laboratory (control sample).

4.2 Evolution of gaseous tracers along the vadose zone - results in water samples

NGT and EA were calculated from Ne-Ar- $\mathrm{N}_{2}$ measured in water samples for low flow (Fig. 4 - red) and high flow (Fig. 4 - blue) periods (Table 3). The mean NGT obtained during the high flow period is $7.9 \pm 2{ }^{\circ} \mathrm{C}$ with $0.007<\chi^{2}<0.6$, while in low flow period the NGT calculated ranges from $18.5^{\circ} \mathrm{C}$ to $26^{\circ} \mathrm{C}\left( \pm 3^{\circ} \mathrm{C}\right)$ with $2.2<\chi^{2}<4.4$. The high NGT values during the low flow period are not consistent with the mean air temperature of the study area (around $11^{\circ} \mathrm{C}$ ). To focus on the evolution of the recharge temperature along the vadose zone, the NGT deviation from the sub-surface point 
396 (Canalettes: $-5 \mathrm{~m}$ ) was calculated. In figure 4, the evolution of the NGT deviation and 397 water temperature evolution are compared.

398 Water temperature increases from $9^{\circ} \mathrm{C}$ close to the surface $(-5 \mathrm{~m})$ to $10.7^{\circ} \mathrm{C}$ at $399-120 \mathrm{~m}$ and $11.1^{\circ} \mathrm{C}$ at the spring. This increase does not correspond to the geothermal 400 gradient, calculated from the mean annual temperature of $11^{\circ} \mathrm{C}$. The vadose zone is 401 therefore influenced by fast water circulation through conduits and fractures that causes 402 thermal convection disturbing the geothermal gradient. The surrounding rock is colder 403 than expected from the application of theoretical geothermal gradients which do not 404 take in account water circulations (Lismonde, 2004).

405 While the water temperature increases with depth, the NGT remains stable 406 during transfer along the vadose zone (Fig. 4). 
Table 3 : Summary of the noble gases, N2 concentrations and recharge conditions (NGT and EA using the UA model) during high flow and low flow at different depths along the vadose zone.

\begin{tabular}{|c|c|c|c|c|c|c|c|c|c|c|c|c|c|}
\hline Name & Date & $\begin{array}{c}\text { Hydrological } \\
\text { context }\end{array}$ & $\begin{array}{l}\text { Depth } \\
\text { (m) }\end{array}$ & $\begin{array}{c}{[\mathrm{Ar}]} \\
(\mathrm{mol} / \mathrm{L}) \\
\pm 5 \%\end{array}$ & $\begin{array}{c}{[\mathrm{Ne}]} \\
(\mathrm{mol} / \mathrm{L}) \\
\pm 8 \%\end{array}$ & $\begin{array}{c}{[\mathrm{N} 2]} \\
(\mathrm{mol} / \mathrm{L}) \\
\pm 5 \%\end{array}$ & $\begin{array}{l}\text { NGT } \\
\left({ }^{\circ} \mathrm{C}\right)\end{array}$ & $\begin{array}{c}\text { Mean NGT } \\
\left({ }^{\circ} \mathrm{C}\right)\end{array}$ & $\begin{array}{c}\mathrm{EA} \\
\left(\mathrm{cm}^{3} \mathrm{STP} / \mathrm{kg}\right)\end{array}$ & $\begin{array}{c}\text { Mean EA } \\
\left(\mathrm{cm}^{3} \mathrm{STP} / \mathrm{kg}\right)\end{array}$ & $\chi^{2}$ & $\begin{array}{l}\text { Delta } \\
\text { NGT } \\
\left({ }^{\circ} \mathrm{C}\right)\end{array}$ & $\begin{array}{c}\text { Delta } \\
\text { EA } \\
\left(\mathrm{cm}^{3} \mathrm{STP}\right. \\
/ \mathrm{kg})\end{array}$ \\
\hline Canalettes & & & -5 & $1.70 \mathrm{E}-05$ & $8.51 \mathrm{E}-09$ & $6.18 \mathrm{E}-04$ & $7.5 \pm 1.7$ & $2.6<6.0<9.2$ & $0 \pm 0.6$ & $0<0.5<1.8$ & 0.17 & 0 & 0 \\
\hline Canalettes & & & & 1.87E-05 & $9.68 \mathrm{E}-09$ & $6.91 \mathrm{E}-04$ & $4.5 \pm 1.9$ & & $0.9 \pm 0.9$ & & 0.30 & & \\
\hline Reynelles & & & -9 & $1.68 \mathrm{E}-05$ & $8.36 \mathrm{E}-09$ & $5.99 \mathrm{E}-04$ & $8.5 \pm 1.7$ & $5.2<8.0<10.2$ & $0 \pm 0.4$ & $0<0.5<1.8$ & 0.44 & 2 & 0 \\
\hline Reynelles & March & & & $1.76 \mathrm{E}-05$ & $9.50 \mathrm{E}-09$ & $6.42 \mathrm{E}-04$ & $7.5 \pm 2.3$ & & $0.9 \pm 0.8$ & & 0.63 & & \\
\hline Jasse & 2018 & High Flow & -45 & $1.65 \mathrm{E}-05$ & $8.85 \mathrm{E}-09$ & $5.96 \mathrm{E}-04$ & $9 \pm 2.3$ & $4.7<8.3<11.3$ & $0.6 \pm 0.7$ & $0<0.7<1.6$ & 0.01 & 2.3 & 0.25 \\
\hline Jasse & & & & $1.74 \mathrm{E}-05$ & $9.33 \mathrm{E}-09$ & $6.40 \mathrm{E}-04$ & $7.5 \pm 2.2$ & & $0.8 \pm 0.8$ & & 0.38 & & \\
\hline Bise & & & -120 & $1.79 \mathrm{E}-05$ & $9.92 \mathrm{E}-09$ & $6.63 \mathrm{E}-04$ & $7.0 \pm 2.2$ & $7.0 \pm 2.2$ & $1.3 \pm 0.9$ & $1.3 \pm 0.9$ & 0.67 & 1 & 0.9 \\
\hline Durzon & & & -167 & $1.77 \mathrm{E}-05$ & $1.04 \mathrm{E}-08$ & $6.93 \mathrm{E}-04$ & $8.0 \pm 2.6$ & $8.0 \pm 2.6$ & $2.3 \pm 1.2$ & $2.3 \pm 1.2$ & 0.07 & 2 & 1.9 \\
\hline Canalettes & & & -5 & $1.22 \mathrm{E}-05$ & $6.69 \mathrm{E}-09$ & $4.00 \mathrm{E}-04$ & $\begin{array}{c}22.0 \pm \\
2.8\end{array}$ & $22.0 \pm 2.8$ & $-1.4 \pm 0.8$ & $-1.4 \pm 0.8$ & 2.2 & 0 & 0 \\
\hline Reynelles & & & -9 & $1.29 \mathrm{E}-05$ & $7.12 \mathrm{E}-09$ & 4.17E-04 & $20 \pm 2.7$ & $16.1<19.3<$ & $-1.3 \pm 0.6$ & $-2<-1.2<-$ & & -2.8 & 0.3 \\
\hline Reynelles & & & & $1.34 \mathrm{E}-05$ & 7.41E-09 & $4.38 \mathrm{E}-04$ & $\begin{array}{c}18.5 \pm \\
2.4\end{array}$ & 22.8 & $-1 \pm 0.6$ & 0.4 & & & \\
\hline
\end{tabular}




\begin{tabular}{|c|c|c|c|c|c|c|c|c|c|c|c|c|c|}
\hline Jasse & Sept & & -45 & $1.19 \mathrm{E}-05$ & $6.61 \mathrm{E}-09$ & $3.83 \mathrm{E}-04$ & $23.5 \pm$ & $18.8<22.3<$ & $-1.5 \pm 0.7$ & $-2.2<-1.5<-$ & 3.1 & 0.3 & -0.1 \\
\hline \multirow[t]{2}{*}{ Jasse } & 2019 & Low Flow & & $1.25 \mathrm{E}-05$ & $6.79 \mathrm{E}-09$ & $4.04 \mathrm{E}-04$ & 2.8 & 26.4 & $-1.5 \pm 0.6$ & 0.8 & 3.2 & & \\
\hline & & & & & & & $21 \pm 2.3$ & & & & & & \\
\hline Bise & & & -120 & $1.14 \mathrm{E}-05$ & $6.68 \mathrm{E}-09$ & $3.70 \mathrm{E}-04$ & $26 \pm 2.6$ & $17.5<22.3<$ & $-1.3 \pm 0.6$ & $-1.9<-0.9<$ & 3.4 & 0.3 & 0.4 \\
\hline Bise & & & & $1.29 \mathrm{E}-05$ & 7.54E-09 & $4.22 \mathrm{E}-04$ & $21 \pm 2.7$ & 8.6 & $-0.8 \pm 0.7$ & 0 & 4.4 & & \\
\hline Bise & & & & $1.33 \mathrm{E}-05$ & 7.64E-09 & 4.33E-04 & $20 \pm 2.7$ & & $-0.7 \pm 0.7$ & & 4.4 & & \\
\hline Durzon & & & -167 & $1.37 \mathrm{E}-05$ & $1.08 \mathrm{E}-08$ & $5.36 \mathrm{E}-04$ & $24 \pm 3.4$ & $15<21.3<27.5$ & $3.2 \pm 1.0$ & $2.2<3.8<$ & 2.8 & -0.8 & 5.2 \\
\hline Durzon & & & & 1.57E-05 & $1.24 \mathrm{E}-08$ & $6.15 \mathrm{E}-04$ & $18.5 \pm$ & & $4.4 \pm 1.1$ & 5.5 & 3.7 & & \\
\hline
\end{tabular}



zone and physico-chemical parameters.

\begin{tabular}{|c|c|c|c|c|c|c|c|c|c|c|c|}
\hline Name & Date & $\begin{array}{c}\text { Hydrological } \\
\text { context }\end{array}$ & $\begin{array}{l}\text { Depth } \\
(\mathrm{m})\end{array}$ & $\begin{array}{c}\text { [CFC-12] } \\
\text { (pmol/L) } \\
\quad \pm 3 \%\end{array}$ & $\begin{array}{c}{\left[\mathrm{SF}_{6}\right]} \\
(\mathrm{pmol} / \mathrm{L}) \\
\pm 5 \%\end{array}$ & $\begin{array}{c}\text { Recharge } \\
\text { Temperature } \\
\left({ }^{\circ} \mathrm{C}\right)\end{array}$ & $\begin{array}{c}\mathrm{EA} \\
\left(\mathrm{cm}^{3} \mathrm{STP} / \mathrm{kg}\right)\end{array}$ & $\begin{array}{c}\text { [CFC-12] } \\
\text { (pptv) } \\
\pm 5 \%\end{array}$ & $\begin{array}{c}{\left[\mathrm{SF}_{6}\right]} \\
\text { (pptv) } \\
\pm 5 \%\end{array}$ & $\begin{array}{c}\mathrm{SpC} \\
(\mu \mathrm{S} / \mathrm{cm} \text { at } \\
\left.25^{\circ} \mathrm{C}\right)\end{array}$ & $\begin{array}{c}\text { Water } \\
\text { Temp } \\
\left({ }^{\circ} \mathrm{C}\right)\end{array}$ \\
\hline Canalettes & & & -5 & 2.5 & 0.0041 & 6 & 0.5 & 408 & 9.2 & 516 & 9.1 \\
\hline Canalettes & & & & 2.6 & 0.0041 & & & 422 & 9.2 & & \\
\hline Reynelles & & & -9 & 2.3 & 0.0035 & 8 & 0.5 & 419 & 8.5 & 471 & 9.0 \\
\hline Reynelles & & & & 2.3 & 0.0035 & & & 419 & 8.5 & & \\
\hline Jasse & & & -45 & 2.1 & 0.0032 & 8.3 & 0.7 & 387 & 7.6 & 395 & 11.3 \\
\hline Jasse & March & & & 2.0 & 0.0030 & & & 412 & 7.2 & & \\
\hline \multirow[t]{2}{*}{ Bise } & 2018 & High Flow & -120 & 2.0 & 0.0027 & 7 & 1.3 & 342 & 5.6 & 468 & 10.7 \\
\hline & & & & 2.4 & 0.0031 & & & 338 & 6.8 & & \\
\hline \multirow[t]{2}{*}{ Durzon } & & & -167 & 2.4 & - & 8 & 2.3 & 436 & - & 476 & 11.1 \\
\hline & & & & 2.3 & - & & & 408 & - & & \\
\hline Canalettes & & & -5 & 2.32 & 0.0013 & 9.1 & 5.5 & 426 & 2.1 & 600 & 10.8 \\
\hline Reynelles & & & -9 & 2.83 & 0.0019 & 9.1 & 5.5 & 519 & 3.0 & 395 & 10.3 \\
\hline Jasse & & & -45 & 3.12 & 0.0031 & 9.1 & 5.5 & 573 & 5.0 & 360 & - \\
\hline Bise & Sept & & -120 & 2.80 & 0.0014 & 9.1 & 5.5 & 427 & 2.2 & 461 & 11 \\
\hline Durzon & 2019 & Low Flow & -167 & 3.03 & 0.0010 & 9.1 & 5.5 & 317 & 1.7 & 428 & 12.1 \\
\hline
\end{tabular}




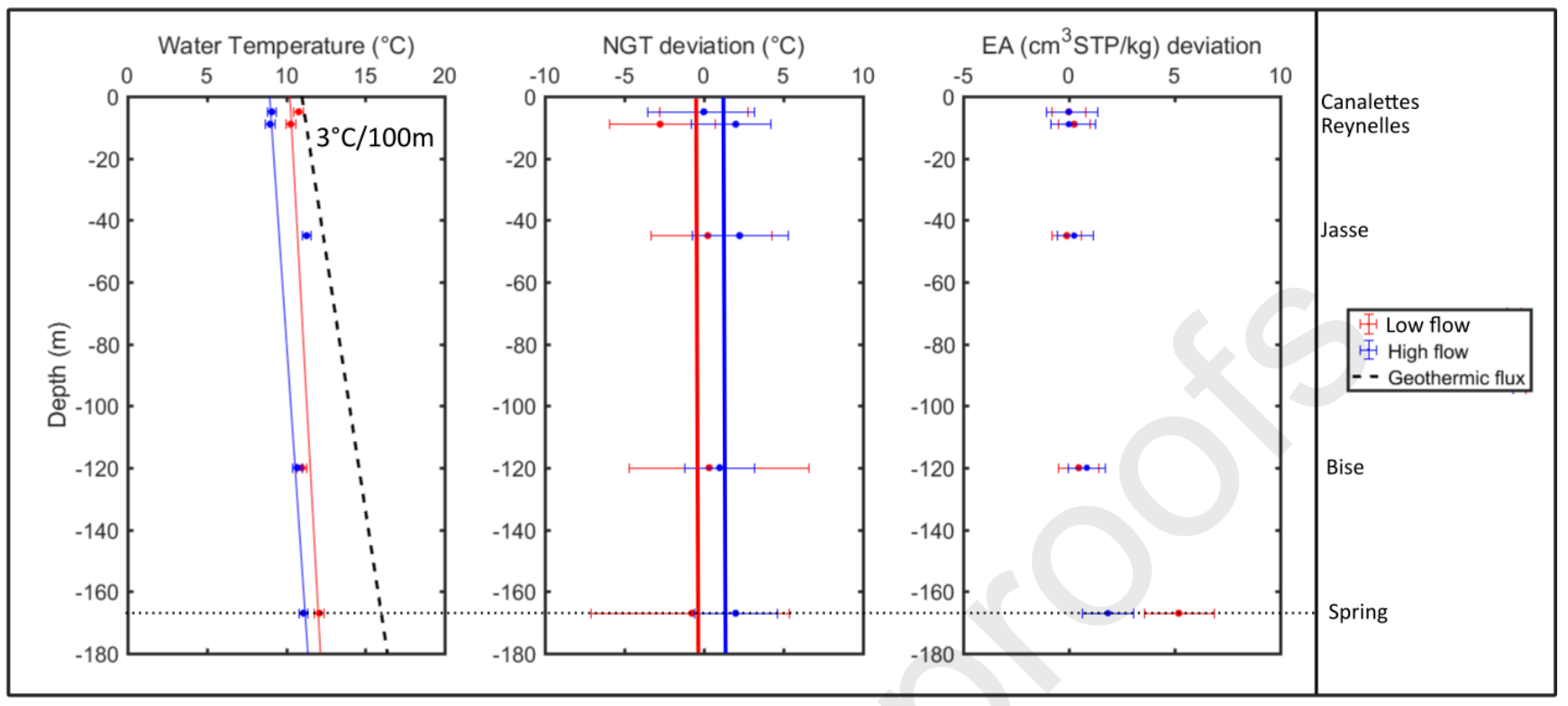

Fig 4: Evolution of water temperature, Noble Gas Temperature (NGT) deviation and Excess Air (EA) deviation during transfer along the vadose zone in high flow (blue point - sampling in March 2018) and low flow (red point sampling in September 2019) - NGT and EA deviations are calculated as changes from the sub-surface points

(Canalettes) in order to compare the evolution of during both campaigns.

For the evolution of the EA in the vadose zone, during the high flow period, the mean EA is $0.6 \mathrm{~cm}^{3} \mathrm{STP} / \mathrm{kg}$ in the unsaturated zone whilst at the spring the EA reaches up to $2.3 \mathrm{~cm}^{3} \mathrm{STP} / \mathrm{kg}$ (Fig. 4 - blue). Similar to the NGT, absolute EA values calculated during the low flow period were underestimated inducing negative values (Fig. 4). We thus used the EA deviation to follow the evolution along the vadose zone, where we observe a slight increase and formation of EA during transfer along the vadose zone.

The historical EA data of the Durzon spring (17 values from 2009 to 2013) shows very large variations during the hydrological cycle; ranging from $0.3 \mathrm{~cm}^{3} \mathrm{STP} / \mathrm{kg}$ during high flow periods to $11 \mathrm{~cm}^{3} \mathrm{STP} / \mathrm{kg}$ during low flow periods. Sampling campaigns of 2018 and 2019 agreed with this historical EA evolution, in spite of the underestimated low flow EA value. The highest values of EA measured at $-120 \mathrm{~m}$ (Table 4) cannot explain the high EA value measured at the spring (up to $10.7 \mathrm{~cm}^{3} \mathrm{STP} / \mathrm{kg}$ in July 2011). Therefore, an additional process contributing to the EA values has to be involved during groundwater flow in the saturated zone. 
The evolution of anthropic dissolved gases CFC-12 vs. SF6 is represented in Fig 5. The samples from the high flow period are aligned according to depth and can be explained by a mixing line between actual water (2018) and an old end-member. $\mathrm{SF}_{6}$ measured at the spring during the high flow period show concentrations higher than the peak atmospheric concentration in 2018, therefore the spring cannot be represented on the CFC-12 vs. SF 6 diagram. However, the CFC-12 values of the spring (between 408 and 412 pptv) are closer to the shallower vadose zone rather than the deeper vadose zone values.

Compared to the high flow samples, the low flow samples have lower SF6 concentrations. There is no correlation between depth and $\mathrm{SF}_{6}$ concentrations during the low flow period. In addition, the samples are better explained by a piston model, in particular Reynelles, or by a piston-exponential model where the exponential component varies between 10 and $50 \%$ (Fig. 5).

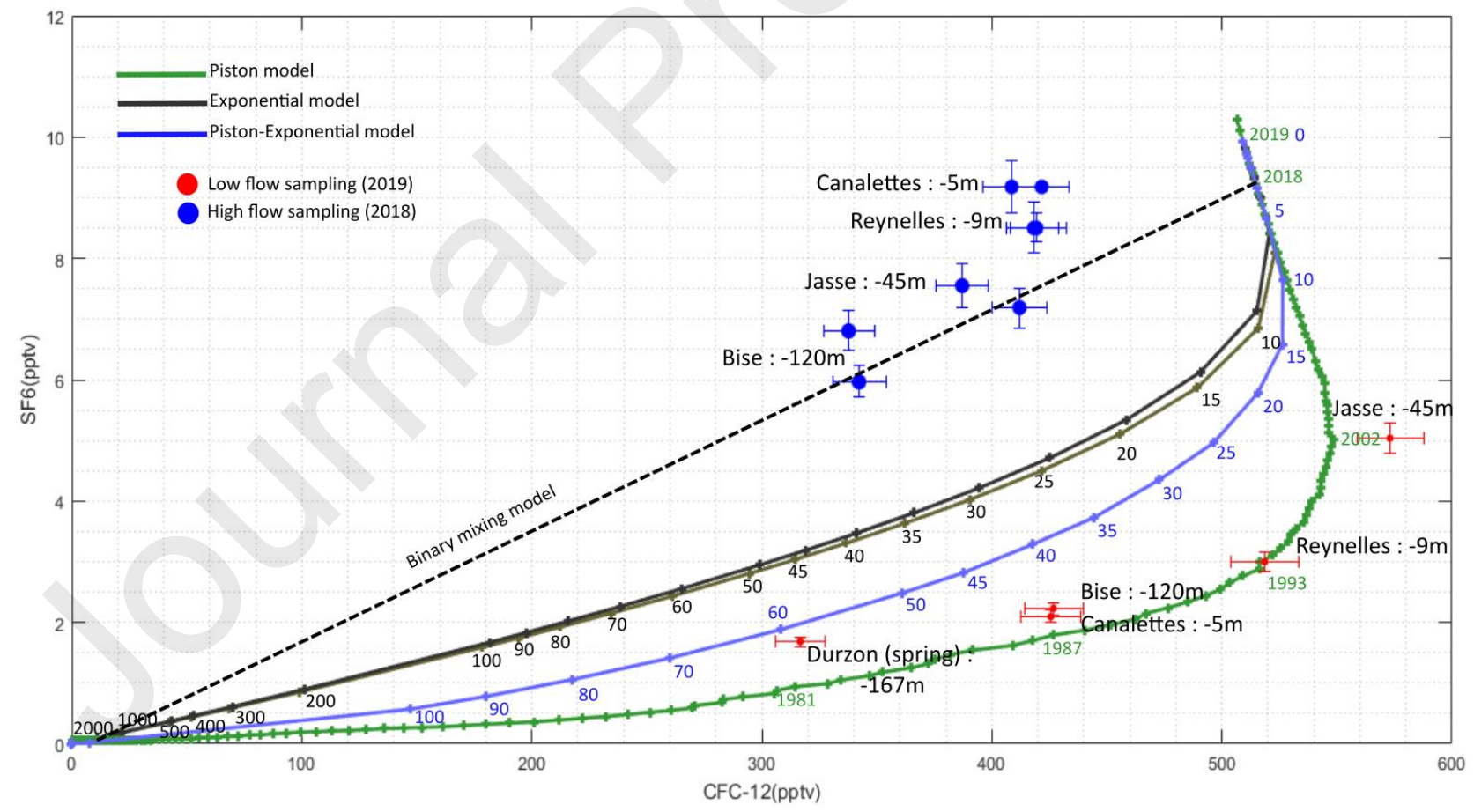

Figure 5: Evolution of $\mathrm{SF}_{6}$ as a function of $\mathrm{CFC}_{12}$ - Blue points: high flow sampling (March 2018); Red points: low flow sampling (September 2019) - Piston pathway model is represented in green 


\section{Discussion}

\subsection{Influence of degassing processes on dissolved gases}

The waters sampled during the low flow period in the vadose zone show low concentrations of noble gases. An underestimation of the dissolved noble gas concentrations results in an overestimation of the recharge temperatures and leads to negative EA values calculated using the Unfraction Air (UA) model. Two hypotheses can explain this underestimation of dissolved gas concentrations: (1) a problem occurred during the laboratory analysis or (2) a degassing phenomenon occurred during the transfer via the vadose zone of the karst. Degassing could explain why the UA model (Heaton and Vogel, 1981) that we used does not provide a good fit $\left(\chi^{2}\right)$ between the observed data and the calculated values (Table 3 - Chi2).

The Partial Re-equilibration (PR) model (Stute et al., 1995) was used as a diagnostic to test the second hypothesis. As we used only three gases (Ne-Ar- $\mathrm{N}_{2}$ ), the NGT was set at $11^{\circ} \mathrm{C}$, which corresponds to the annual mean air temperature in the catchment, allowing us to add the fractionation coefficient $(F)$ as a parameter to be set, with the EA. However, the PR model did not reproduce the observations nor the positive EA values along the vadose zone.

A model taking into account degassing does not therefore seem to better explain the values measured during the low flow period. This result is in good agreement with historical measured at the Durzon spring (since 2011); where no negative EA values were observed and for which the UA model well reproduced the EA and NGT values.

The analytical error is observed for all of the data for the same field campaign, therefore the absolute values are not possible to use, however the relative changes in the data (deviation) is valid and can be compared to relative changes from other field campaigns. 


\subsection{Impact of the epikarst and the unsaturated zone on air and water transfers}

\subsubsection{Gas transfer within the vadose zone}

The measurement of matrix air within the epikarst and at different depths in the unsaturated zone constitutes a real scientific challenge due to the complexity of the underground environment within the karst systems, where accessibility and material input is not always possible. The results of this study show that the air in the cavities of the vadose zone of the Durzon catchment is in equilibrium with atmospheric air down to $120 \mathrm{~m}$ depth (Figs. 2 and 3). Only gaseous $\mathrm{CO}_{2}$ increases with depth in the vadose zone and presents higher values in low flow period than in the high flow period. The evolution of gaseous $\mathrm{CO}_{2}$ between high flow and low flow periods reflects the seasonal rhythm of the biomass with a higher production of $\mathrm{CO}_{2}$ during summer (Paterson and Sweeting, 1986; Batiot-Guilhe et al., 2007). The flux of $\mathrm{CO}_{2}$ moves down by diffusion and gravity from the top of the vadose zone (production area: epikarst) to the bottom, explaining the accumulation of $\mathrm{CO}_{2}$ during transfer along the vadose zone.

For the Durzon karstic system, the dolomitic epikarst zone may include a perched aquifer (Plagnes, 1997, Fores et al., 2017). The results of this study suggest that the perched aquifer located in the surface horizons of the vadose zone of the karst does not cause a disconnection between the air mass of the vadose zone and the atmosphere. The gas results show that the epikarst must be seen as a very heterogeneous and discontinuous medium which allows both the storage of a volume of water (perched nappe) but also the transfer of air along the vadose zone via sub-vertical conduits, some of which can be penetrated by speleologists (up to $120 \mathrm{~m}$ deep).

Cavities in the vadose zone of the karst are well aerated, unlike porous media where a delay factor must be calculated to take into account gas diffusion (Busenberg and Plummer, 1992; Cook and Solomon, 1995; Oster et al., 1996; Zoellmann et al., 2000; Schwientek et al., 2009). In karst environments, despite the existence of a vadose zone of several tens or even hundreds of metres thick, it is not necessary to calculate a gas delay or diffusion coefficients to consider the transfer of air to the saturated zone. These results are nevertheless limited to the transmissive component of the karst, 
i.e. the drains and cavities, and cannot be generalised to the capacitive component represented by the porous matrix of the rock, which was not analysed in this study.

\subsubsection{Gas equilibrium}

Using gaseous tracers in hydrosystems characterised by a perched aquifer (epikarst) located above a thick unsaturated zone raises important questions on gas equilibrium processes during transfers. For example, does the tracing start at the top of the vadose zone composed of a capacitive epikarst? Is there any equilibrium with the cave's air above? Or does the tracing start at the top of the saturated zone? In this study, at $120 \mathrm{~m}$ depth the air temperature is buffered at $10.8^{\circ} \mathrm{C}$ all year round at the Durzon site. High flow sampling was carried out at the time of a snow recharge episode, indicating a surface air temperature close to $0^{\circ} \mathrm{C}$. Thus, large variations in air temperature between the surface and the bottom of the vadose zone are suspected. Despite this, no variations were observed in the NGT calculated from the dissolved gases (Fig. 4). This stability in the NGT results (around $8 \pm 2^{\circ} \mathrm{C}$ ) throughout the profile of the vadose zone indicates that there is no rebalancing of the dissolved gases in the water with the air in the cavities. The results are similar in low flow periods, confirming that noble gas equilibrium occurs in the near-surface horizon at the epikarst.

During high flow periods, according to the evolution of $\mathrm{SF}_{6}$ as a function of CFC-12, mixing is observed between the rapid infiltration of recent water from the surface and older water stored in the matrix porosity of the karst unsaturated zone (Fig. 5). With increasing depth in the vadose zone, the portion of recently infiltrated water decreases relative to the older pore matrix water. Therefore, the surface horizons have greater volumes of more recent waters compared with the deeper horizons of the vadose zone, which likely reflects transfer times within the vadose zone. This difference in mixing as a function of depth also highlights the fact that there is no resetting of the equilibrium between water and air in the cavities during transfer along the vadose zone, and similar to noble gas results, the gas equilibrium occurs in the sub-surface horizon. The mixing of groundwater of different flow pathways from the unsaturated zone and the saturated zone at the spring could explain the supposed non-alignment of CFC-12 concentrations of the spring with samples from the vadose zone with depth. 
During low flow periods, similar to the high flow period, the water sampled at different depths of the vadose zone does not show a current atmospheric gas signature, which indicates there is no equilibrium with the air in the cavities during the low flow period. However, no correlation with the vadose zone depth is observed. Different processes are involved in water transfers that are not dependent on depth. The identification of these low flow processes requires further work.

\subsection{EA formation}

Two main hypothesis are proposed in previous studies to explain the EA formation: formation during the transfer along the vadose zone (Herzberg and Mazor, 1979) and/or acquisition of the EA due to water level variations (Aeschbach-Hertig, 2004).

The evolution of EA suggests a slight increase of the signal during the transfer of water along the vadose zone $\left(+0.8 \mathrm{~cm}^{3} \mathrm{STP} / \mathrm{kg}\right.$ during high flow period, Fig. 4). This enrichment in EA may be due to pressure variations within the vadose zone. Another hypothesis that could explain the enrichment of water in EA during its transfer along the vadose zone would be a flow that is sufficiently fast to cause air bubbles whose dissolution will be forced during a deep pressurisation (Herzberg and Mazor, 1979). However, the EA values observed during low flow and high flow periods at a depth of $120 \mathrm{~m}$ do not explain the maximum values measured at the spring. Further work in the Durzon catchment would be required to comment on the spatial representation of vadose zone results from this study relative to the whole catchment area. Nevertheless, the significantly greater EA values of the spring compared with the vadose zone (up to almost 5 times greater) suggests that the formation of EA does not solely depend on the transfer along the vadose zone.

Holocher (2002) experimentally investigated the formation of EA in near-saturated porous media using vertical sand columns. Simulating variations of the water level, he obtained a correlation between these variations and the measured EA between 0.14 and $1.62 \mathrm{~cm}^{3} \mathrm{STP} / \mathrm{kg}$ for maximum variations of the piezometric level of one meter. The values observed in the literature are generally low (less than $2 \mathrm{~cm}^{3} \mathrm{STP} / \mathrm{kg}$ ), whilst EA values in the Durzon karstic system are high, up to $11 \mathrm{~cm}^{3} \mathrm{STP} / \mathrm{kg}$. These high EA 
values seem to highlight the combination of factors favourable to EA formation in Mediterranean-type karstic systems such as:

- Intense recharge events known as Cevenol episodes (particular to the Mediterranean region);

- An aquifer structure that combines both a porous medium and conduits allowing strong and rapid elevations of the water table that results in the dissolution of trapped air bubbles;

With this configuration, the EA acts as a tracer of the magnitude of groundwater fluctuations, and therefore a tracer of recharge areas. Many points are still yet to be clarified, such as the influence of the lithological nature of the aquifer, which raises the question of whether the same answers would be found in a non-dolomitic karst. In addition, it is unknown whether there is a direct link between EA and rainfall recharge rates. Lastly, from the perspective of modelling the evolution of EA coupled with hydrodynamics, it is not yet clear whether we should expect a "zero" reset of EA after each hydrological cycle or on the contrary a long-term cumulative effect could be expected?

\section{Conclusion}

The use of dissolved gases as tracers in karstic aquifers, renowned for their air cavities in thick unsaturated zones and epikarsts, raises many questions relating to methods and applications. The composition and impact of air in the subsurface, where the dissolved gas equilibrium takes place along the vertical profile of the thick vadose zone, and the conditions of EA formation are still debated.

In this research, these questions were addressed by monitoring the evolution of noble and anthropogenic gases ( $\mathrm{Ne}, \mathrm{Ar}, \mathrm{N}_{2}, \mathrm{CFC}$ and $\mathrm{SF}_{6}$ ) in air and water along the vadose zone of the Durzon and the Ironselle catchments during two contrasted flow periods (low flow and high flow). The determination of the cave air composition and its comparison with the water concentrations show that at the Durzon site:

1. Air in caves was in equilibrium with the atmospheric air up to $120 \mathrm{~m}$ deep; 
2. The presence of a capacitive epikarst does not disconnect the unsaturated zone from the atmosphere;

3. The gas equilibrium appears to be achieved in a horizon close to the surface and then there is no gaseous re-equilibrium between air and water with depth in the vadose zone;

4. A small part of EA is formed during water transfer along the vadose zone but most of the EA observed at the spring is formed due to the water level variations of the saturated zone.

These observations indicate that there is no need to take into account a timelag coefficient associated with the gas dispersion into the unsaturated zone of a karst system. This information is essential for the use of temporal gaseous tracers in karstic systems. Finally, the strong link between EA and discharge suggests the development of $E A$ as a tracer of recharge in karst aquifers.

Therefore, for karstic aquifers where the hydrodynamics are complex, the EA provides a valuable tracer of variations in groundwater levels. Future work is required to integrate EA data into numerical models. This integration of the gas results with hydrodynamic models would be useful to bring a new constraint to numerical models. In karst systems, future research is required to study the reaction of gas tracers in other lithologies, such as limestone environments. As observed in this study, the formation of EA (and therefore the reaction of gases) is strongly linked to the karstic aquifer structures.

\section{Acknowledgements:}

We are grateful to G. Barrau and L. Martin (HSM) who helped for the sampling campaign in particular the sample at $120 \mathrm{~m}$ deep on the Durzon catchment and $\mathrm{E}$. Boyer, C. Siry, J. Poisson, C. Perret, R. Boulouis, H. Danguy, A. Pierrot, S. Teskrat and A. Jacquet who sampled at $400 \mathrm{~m}$ deep on the Ironselle catchment. We also thank the Regional Natural Park of the Grands Causses for allowing us to use their data from the Durzon spring. Dissolved gas analyses were performed within the CONDATE-EAU analytical platform, that we also acknowledge for the several discussions. 


\section{Bibliography}

Aeschbach-Hertig, W., 2004. Excess Air in Groundwater: Problems and Opportunities. Annual Meeting of GSA, Denver

Aeschbach-Hertig, W., Peeters, F., Beyerle, U., Kipfer, R., 2000. Palaeotemperature reconstruction from noble gases in ground water taking into account equilibration with entrapped air. Nature 405, 1040-1044. https://doi.org/10.1038/35016542

Aeschbach-Hertig, W., Peeters, F., Beyerle, U., Kipfer, R., 1999. Interpretation of dissolved atmospheric noble gases in natural waters. Water Resources Research 35, 27792792. https://doi.org/10.1029/1999WR900130

Aeschbach-Hertig, W., Solomon, D.K., 2013. Noble Gas Thermometry in Groundwater Hydrology, in: Burnard, P. (Ed.), The Noble Gases as Geochemical Tracers. Springer Berlin Heidelberg, Berlin, Heidelberg, pp. 81-122. https://doi.org/10.1007/978-3642-28836-4_5

Andrews, J.N., Lee, D.J., 1979. Inert gases in groundwater from the Bunter Sandstone of England as indicators of age and palaeoclimatic trends. Journal of Hydrology 41, 233-252. https://doi.org/10.1016/0022-1694(79)90064-7

Aquilina, L., Ladouche, B., Dörfliger, N., 2005. Recharge processes in karstic systems investigated through the correlation of chemical and isotopic composition of rain and spring-waters. Applied Geochemistry 20, 2189-2206. https://doi.org/10.1016/j.apgeochem.2005.07.011

Arbel, Y., Greenbaum, N., Lange, J., Inbar, M., 2010. Infiltration processes and flow rates in developed karst vadose zone using tracers in cave drips. Earth Surface Processes and Landforms 35, 1682-1693. https://doi.org/10.1002/esp.2010

Bailly-Comte, V., Jourde, H., Roesch, A., Pistre, S., 2008. Mediterranean flash flood transfer through karstic area. Environmental Geology 54, 605-614. https://doi.org/10.1007/s00254-007-0855-y

Bakalowicz, M., 2008. Le milieu karstique: études et perspectives, identification et caractérisation de la ressource 17. Comité Français d'Hydrogéologie - Colloque Hydrogéologie et karst

Bakalowicz, M., 2005. Karst groundwater: a challenge for new resources. Hydrogeology Journal 13, 148-160. https://doi.org/10.1007/s10040-004-0402-9 
Bakalowicz, M., 2004. The epikarst: the skin of the karst 8. Karst Waters Institute special Publication 9

Ballentine, C.J., Hall, C.M., 1999. Determining paleotemperature and other variables by using an error-weighted, nonlinear inversion of noble gas concentrations in water. Geochimica et Cosmochimica Acta 63, 2315-2336. https://doi.org/10.1016/S00167037(99)00131-3

Barnes, C.J., Allison, G.B., 1988. Tracing of water movement in the unsaturated zone using stable isotopes of hydrogen and oxygen. Journal of Hydrology 143-176. https://doi.org/10.1016/0022-1694(88)90184-9

Batiot-Guilhe, C., Seidel, J.-L., Jourde, H., Hébrard, O., Bailly-Comte, V., 2007. Seasonal variations of $\mathrm{CO}_{2}$ and $222 \mathrm{Rn}$ in a mediterranean sinkhole - spring (Causse d'Aumelas, SE France). International Journal of Speleology 36, 51-56. https://doi.org/10.5038/1827-806X.36.1.5

Blicher-Mathiesen, G., McCarty, G.W., Nielsen, L.P., 1998. Denitrification and degassing in groundwater estimated from dissolved dinitrogen and argon. Journal of Hydrology 208, 16-24. https://doi.org/10.1016/S0022-1694(98)00142-5

Bruxelles, L., 2001. Dépôts et altérites des plateaux du Larzac central: causses de I'Hospitalet et de Campestre (Aveyron, Gard, Hérault) - Evolution morphogénétique, conséquences géologiques et implications pour l'aménagement. Thesis. Aix-Marseille, France.

Busenberg, E., Plummer, L.N., 1992. Use of Chlorofluorocarbons (CCl3F and CCl2F2) as HydrologicTracers and Age-Dating Tools: The Alluvium and Terrace System of Central Oklahoma. Water Resources Research 28, 2257-2283. https://doi.org/10.1029/92WR01263

Carrasco, F., Andreo, B., Liñán, C., Mudry, J., 2006. Contribution of stable isotopes to the understanding of the unsaturated zone of a carbonate aquifer (Nerja Cave, southern Spain). Comptes Rendus Geoscience 338, 1203-1212. https://doi.org/10.1016/j.crte.2006.09.009

Chatton, E., Aquilina, L., Pételet-Giraud, E., Cary, L., Bertrand, G., Labasque, T., Hirata, R., Martins, V., Montenegro, S., Vergnaud, V., Aurouet, A., Kloppmann, W., Pauwels, 2016. Glacial recharge, salinisation and anthropogenic contamination in 
the coastal aquifers of Recife (Brazil). Science of The Total Environment 569570, 1114-1125. https://doi.org/10.1016/j.scitotenv.2016.06.180

Cook, P.G., Solomon, D.K., 1995. Transport of Atmospheric Trace Gases to the Water Table: Implications for Groundwater Dating with Chlorofluorocarbons and Krypton 85. Water Resources Research 31, 263-270. https://doi.org/10.1029/94WR02232 de Montety, V., Bondu-Crozel, R., Aquilina, L., Batiot, C., Seidel, J.-L., Labasque, T., 2012. Dissolved gases: new tracers of recharge mechanisms and flow dynamics in Karst. Groundwater Dating Meeting (GDAT) 2012, Rennes

Deville, S., 2013. Caractérisation de la zone non saturée des karsts par la gravimétrie et l'hydrogéologie. Thesis. Montpellier

Fairchild, I.J., Tuckwell, G.W., Baker, A., Tooth, A.F., 2006. Modelling of dripwater hydrology and hydrogeochemistry in a weakly karstified aquifer (Bath, UK): Implications for climate change studies. Journal of Hydrology 321, 213-231. https://doi.org/10.1016/j.jhydrol.2005.08.002

Fleury, P., Plagnes, V., Bakalowicz, M., 2007. Modelling of the functioning of karst aquifers with a reservoir model: Application to Fontaine de Vaucluse (South of $\begin{array}{llll}\text { France). Journal Hydrology 38-49. } & \text { of }\end{array}$ https://doi.org/10.1016/j.jhydrol.2007.07.014

Fores, B., 2016. Gravimétrie et surveillance sismique pour la modélisation hydrologique en milieu karstique. Application au bassin du Durzon (Larzac, France). Thesis. Montpellier, France.

Fores, B., Champollion, C., Le Moigne, N., Bayer, R., Chéry, J., 2017. Assessing the precision of the iGrav superconducting gravimeter for hydrological models and karstic hydrological process identification. Geophysical Journal International 208, 269-280. https://doi.org/10.1093/gji/ggw396

Garry, B., Blondel, T., Emblanch, C., Sudre, C., Bilgot, S., Cavaillou, A., Boyer, D., Auguste, M., 2008. Contribution of artificial galleries to the knowledge of karstic system behaviour in addition to natural cavern data. International Journal of Speleology 37, 75-82. https://doi.org/10.5038/1827-806X.37.1.7

Goldscheider, N., Chen, Z., Auler, A.S., Bakalowicz, M., Broda, S., Drew, D., Hartmann, J., Jiang, G., Moosdorf, N., Stevanovic, Z., Veni, G., 2020. Global distribution of 
carbonate rocks and karst water resources. Hydrogeology Journal 28, 1661-1677. https://doi.org/10.1007/s10040-020-02139-5

Heaton, T.H.E., Vogel, J.C., 1981. "Excess Air" in groundwater. Journal of Hydrology 50, 201-216. https://doi.org/10.1016/0022-1694(81)90070-6

Herzberg, O., Mazor, E., 1979. Hydrological applications of noble gases and temperature measurements in underground water systems: Examples from Israel. Journal of Hydrology 41, 217-231. https://doi.org/10.1016/0022-1694(79)90063-5

Ingram, R.G.S., Hiscock, K.M., Dennis, P.F., 2007. Noble Gas Excess Air Applied to Distinguish Groundwater Recharge Conditions. Environmental Science \& Technology 41, 1949-1955. https://doi.org/10.1021/es061115r

IAEA, 2006. Use of Chlorofluorocarbons in hydrology Inter: A Guidebook. Vienna. <http://www-pub.iaea.org/MTCD/publications/PDF/Pub1238_web.pdf>

Jacob, T., 2009. Apport de la gravimétrie et de l'inclinométrie à l'hydrologie karstique (Géophysique). Thesis. Montpellier II, France.

Jeannin, P.-Y., 1998. Structure et comportement hydraulique des aquifères karstiques. Thesis. Neuchatel, Suisse.

Klimchouk, A., 2004. Towards defining, delimiting and classifying epikarst: Its origin, processes and variants of geomorphic evolution. Speleogenesis and Evolution of Karst Aquifers 2, 12.

Klimchouk, A., Ford, D., Palmer, A., 2000. The formation of epikarst and its role in vadose speleogenesis, in: Speleogenesis: Evolution of Karst Aquifers. pp. 91-99.

Kluge, T., Riechelmann, D.F.C., Wieser, M., Spötl, C., Sültenfuß, J., Schröder-Ritzrau, A., Niggemann, S., Aeschbach-Hertig, W., 2010. Dating cave drip water by tritium. Journal of Hydrology 394, 396-406. https://doi.org/10.1016/j.jhydrol.2010.09.015

Knierim, K.J., Pollock, E., Hays, P.D., 2013. Using isotopes of dissolved inorganic carbon species and water to separate sources of recharge in a cave spring, northwestern Arkansas, USA. Carsologica 261-276. https://doi.org/10.3986/ac.v42i2-3.667

Kogovsek, J., Petric, M., 2014. Solute transport processes in a karst vadose zone characterized by long-term tracer tests (the cave system of Postojnska Jama, Slovenia). Journal of Hydrology 519, 1205-1213. https://doi.org/10.1016/j.jhydrol.2014.08.047 
Labasque, T., Aquilina, L., Vergnaud, V., Hochreutener, R., Barbecot, F., Casile, G., 2014. Inter-comparison exercises on dissolved gases for groundwater dating - (1) Goals of the exercise and site choice, validation of the sampling strategy. Applied Geochemistry 40, 119-125. https://doi.org/10.1016/j.apgeochem.2013.11.007

Labasque, T., Ayraud, V., Aquilina, L., Corre, P.L., 2006. Dosage des composés chlorofluorocarbonés et du tétrachlorure de carbone dans les eaux souterraines. Application à la datation des eaux. 51.

Lismonde, B., 2004. Le flux géothermique avec circulation d'eau profonde dans les karsts: la surprise des transitoires. Karstologia : revue de karstologie et de spéléologie physique 44, 51-55. https://doi.org/10.3406/karst.2004.2554

Manning, A.H., Solomon, D.K., 2003. Using noble gases to investigate mountain-front recharge. Journal of Hydrology 275, 194-207. https://doi.org/10.1016/S00221694(03)00043-X

Mariotti, A., 1986. La dénitrification dans les eaux souterraines, principes et méthodes de son identification: une revue. Journal of Hydrology 88, 1-23. https://doi.org/10.1016/0022-1694(86)90194-0

Massmann, G., Sültenfub, J., 2008. Identification of processes affecting excess air formation during natural bank filtration and managed aquifer recharge. Journal of Hydrology 235-246. https://doi.org/10.1016/j.jhydrol.2008.07.004

Mazor, E., van Everdingen, R.O., Krouse, H.R., 1983. Noble-gas evidence for geothermal activity in a karstic terrain: Rocky Mountains, Canada. Geochimica et Cosmochimica Acta 47, 1111-1115. https://doi.org/10.1016/0016-7037(83)902417

Mudry, J., Puig, J.-M., 1991. Le karst de la fontaine de Vaucluse (Vaucluse, Alpes de Haute-Provence, Drôme). Karstologia : revue de karstologie et de spéléologie physique 18, 29-38. https://doi.org/10.3406/karst.1991.2268

Musgrove, M., Banner, J.L., 2004. Controls on the spatial and temporal variability of vadose dripwater geochemistry: Edwards aquifer, central Texas. Geochimica et Cosmochimica Acta 68, 1007-1020. https://doi.org/10.1016/j.gca.2003.08.014 
Oster, H., Sonntag, C., Münnich, K.O., 1996. Groundwater age dating with chlorofluorocarbons. Water Resources Research 32, 2989-3001. https://doi.org/10.1029/96WR01775

Paterson, K., Sweeting, M.M., 1986. New directions in karst: proceedings of the AngloFrench Karst Symposium. Norwich: Geo Books.

Perrin, J., Jeannin, P.-Y., Zwahlen, F., 2003. Epikarst storage in a karst aquifer: a conceptual model based on isotopic data, Milandre test site, Switzerland. Journal of Hydrology 279, 106-124. https://doi.org/10.1016/S0022-1694(03)00171-9

Pinault, J.-L., Plagnes, V., Aquilina, L., Bakalowicz, M., 2001. Inverse modeling of the hydrological and the hydrochemical behavior of hydrosystems: Characterization of Karst System Functioning. Water Resources Research 37, 2191-2204. https://doi.org/10.1029/2001WR900018

Plagnes, V., 1997. Structure et fonctionnement des aquifères karstiques. Caractérisation par la géochimie des eaux. Thesis. Montpellier II, France.

Plummer, L.N., Busenberg, E., Widman, P.K., 2004. Applications of Dissolved N2 and Ar in Groundwater. U.S. Geological Survey, Reston, Virginia, USA.

Poulain, A., Rochez, G., Bonniver, I., Hallet, V., 2015. Stalactite drip-water monitoring and tracer tests approach to assess hydrogeologic behavior of karst vadose zone: case study of Han-sur-Lesse (Belgium). Environmental Earth Sciences 7685-7697. https://doi.org/10.1007/s12665-015-4696-9

Ricard, J., Bakalowicz, M., 1996. Connaissance, aménagement et protection des ressources en eau du Larzac Septentional, Aveyron (France). Rapport BRGM R38953, 94p., 200 annexes.

Sánchez, D., Barberá, J.A., Mudarra, M., Andreo, B., 2015. Hydrogeochemical tools applied to the study of carbonate aquifers: examples from some karst systems of Southern Spain. Environmental Earth Sciences 74, 199-215. https://doi.org/10.1007/s12665-015-4307-9

Sano, Y., Marty, B., Burnard, P., 2013. Noble Gases in the Atmosphere, in: The Noble Gases as Geochemical Tracers. pp. 17-31. 
Schwientek, M., Maloszewski, P., Einsiedl, F., 2009. Effect of the unsaturated zone thickness on the distribution of water mean transit times in a porous aquifer. Journal of Hydrology 373, 516-526. https://doi.org/10.1016/j.jhydrol.2009.05.015

Šimůnek, J., Jarvis, N.J., van Genuchten, M.Th., Gärdenäs, A., 2003. Review and comparison of models for describing non-equilibrium and preferential flow and transport in the vadose zone. Journal of Hydrology 272, 14-35. https://doi.org/10.1016/S0022-1694(02)00252-4

Smith, R.L., Howes, B.L., Duff, J.H., 1991. Denitrification in nitrate-contaminated groundwater: Occurrence in steep vertical geochemical gradients. Geochimica et Cosmochimica Acta 55, 1815-1825. https://doi.org/10.1016/0016-7037(91)900262

Stevanović, Z., 2019. Karst waters in potable water supply: a global scale overview. Environmental Earth Sciences 78. https://doi.org/10.1007/s12665-019-8670-9

Stevanović, Z., 2018. Global distribution and use of water from karst aquifers. Geological Society, London, Special Publications 466, 217-236. https://doi.org/10.1144/SP466.17

Stute, M., Clark, J.F., Schlosser, P., Broecker, W.S., Bonani, G., 1995. A 30,000yr continental paleotemprature record derived from noble gases dissolved in groundwater from San Juan Basin, New Mexico. Quaternary Research 43, 209220. https://doi.org/10.1006/qres.1995.1021

Stute, M., Forster, M., Frischkorn, H., Serejo, A., Clark, J.F., Schlosser, P., Broecker, W.S., Bonani, G., 1995. Cooling of Tropical Brazil (5 C) During the Last Glacial Maximum. Science 269, 379-383. https://doi.org/10.1126/science.269.5222.379

Stute, M., Schlosser, P., 2000. Atmospheric Noble Gases, in: Cook, P.G., Herczeg, A.L. (Eds.), Environmental Tracers in Subsurface Hydrology. Springer US, Boston, MA, pp. 349-377. https://doi.org/10.1007/978-1-4615-4557-6_11

Tooth, A.F., Fairchild, I.J., 2003. Soil and karst aquifer hydrological controls on the geochemical evolution of speleothem-forming drip waters, Crag Cave, southwest Ireland. Journal of Hydrology 273, 51-68. https://doi.org/10.1016/S00221694(02)00349-9 
Tritz, S., Guinot, V., Jourde, H., 2011. Modelling the behaviour of a karst system catchment using non-linear hysteretic conceptual model. Journal of Hydrology 397, 250-262. https://doi.org/10.1016/j.jhydrol.2010.12.001

Vereecken, H., Huisman, J.A., Bogena, H., Vanderborght, J., Vrugt, J.A., Hopmans, J.W., 2008. On the value of soil moisture measurements in vadose zone hydrology: $A$ review: Soil moisture and hydrology. Water Resources Research 44. https://doi.org/10.1029/2008WR006829

Weiss, R.F., 1971. Solubility of helium and neon in water and seawater. Journal of Chemical \& Engineering Data 16, 235-241. https://doi.org/10.1021/je60049a019

Weiss, R.F., 1970. The solubility of nitrogen, oxygen and argon in water and seawater. Deep Sea Research and Oceanographic Abstracts 17, 721-735. https://doi.org/10.1016/0011-7471(70)90037-9

Williams, P.W., 1983. The role of the subcutaneous zone in karst hydrology. Journal of Hydrology 45-67. https://doi.org/10.1016/0022-1694(83)90234-2

Zoellmann, K., Kinzelbach, W., Fulda, C., 2000. Environmental tracer transport (3H and SF6) in the saturated and unsaturated zones and its use in nitrate pollution management. Journal of Hydrology 240, 187-205. https://doi.org/10.1016/S00221694(00)00326-7

NOAA.gov. Trends in Atmospheric Carbon Dioxyde [en ligne]. (15/04/2020). https://www.esrl.noaa.gov/gmd/hats/data.html 
- We sampled air and water at different depths until $120 \mathrm{~m}$ along a thick vadose zone

- We investigated transfers of gas and groundwater through a thick vadose zone

- We investigated Excess Air formation in a karstic system with a thick vadose zone

- The air of the vadose zone is in equilibrium with the atmosphere until $120 \mathrm{~m}$

- The main part of Excess Air is formed due to water table variations 
Laïna Pérotin: Conceptualization, Software, Formal analysis, Investigation, Writing - Original Draft, Project administration

Véronique de Montéty: Conceptualization, Investigation, Writing - Review \& Editing, Funding acquisition, Supervision

Bernard Ladouche: Conceptualization, Funding acquisition, Writing - Review \& Editing, Supervision

Vincent Bailly-Comte: Investigation, Writing - Review \& Editing

Thierry Labasque: Resources

Rémi Muller: Investigation

Cédric Champollion: Funding acquisition, Writing - Review \& Editing

Sarah Tweed: Funding acquisition, Writing - Review \& Editing

Jean-Luc Seidel: Funding acquisition 